\title{
ENHANCING COMPETITION CONDITIONS AND COMPETITIVENESS OF PHILIPPINE DOMESTIC SHIPPING
}

September 2014

The World Bank and International Finance Corporation

Philippine Country Office

East Asia and Pacific Region

A project of the World Bank, with the support of the Australian Government through the Australia-World Bank Philippines Development Trust Fund

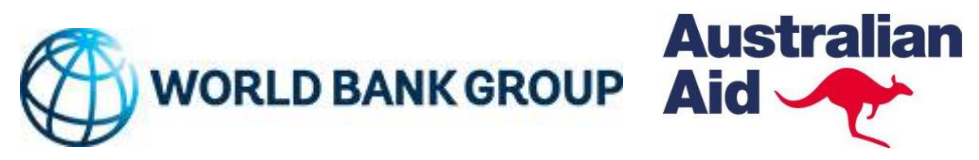

Document of the World Bank Group 


\section{Enhancing competition conditions and competitiveness of Philippine domestic shipping services $^{1}$}

\section{Contents}

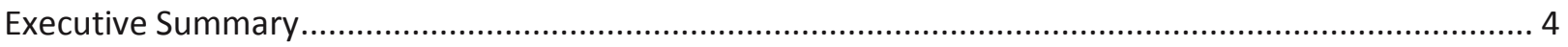

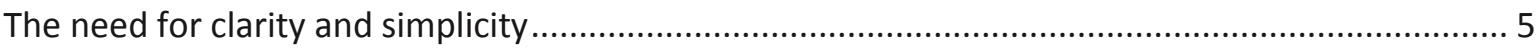

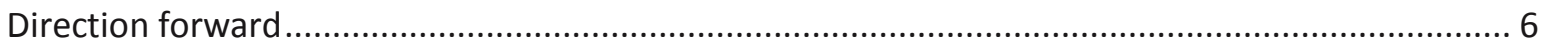

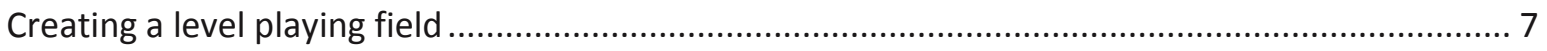

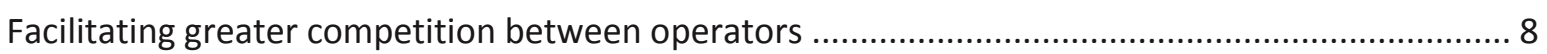

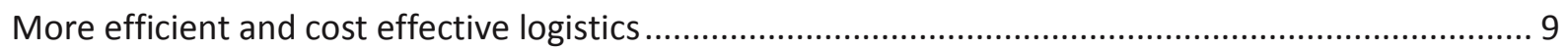

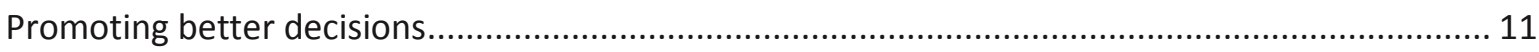

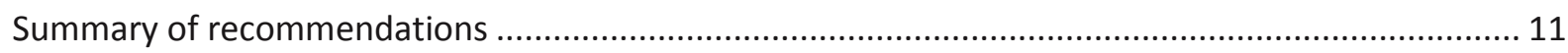

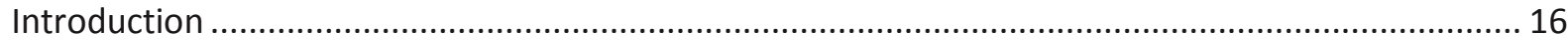

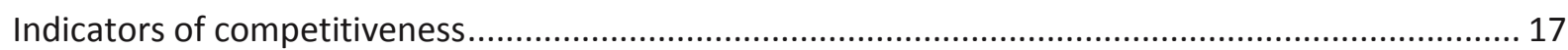

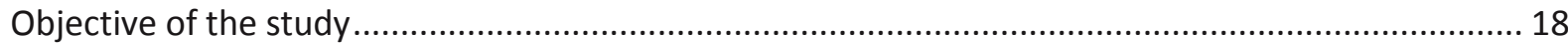

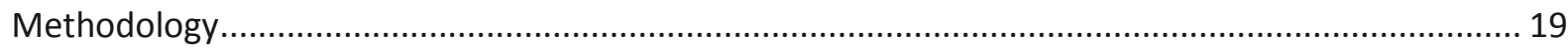

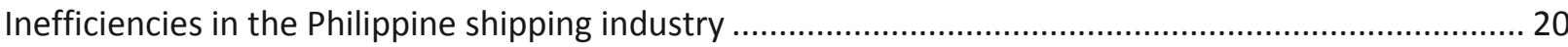

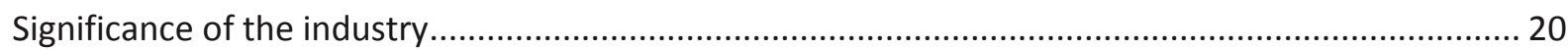

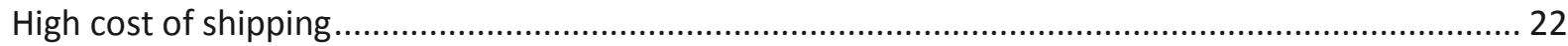

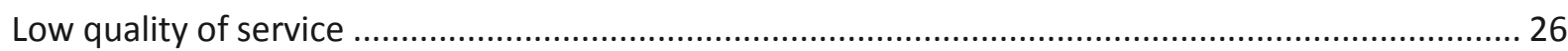

Poor safety record and high frequency of maritime accidents .................................................... 26

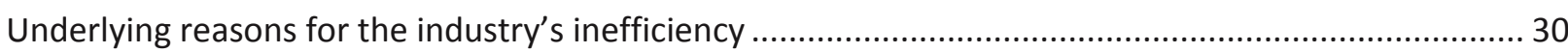

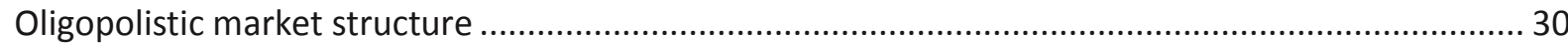

Increased competition yet low profitability ............................................................................... 32

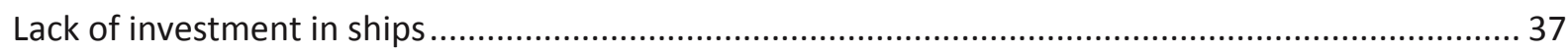

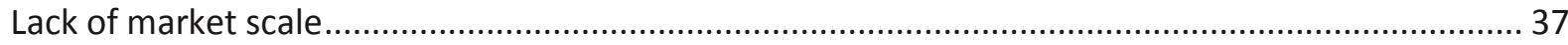

Exacerbated by the lack of connectivity, network planning, and consolidation ................................. 39

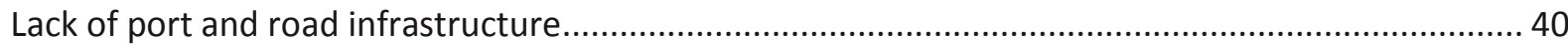

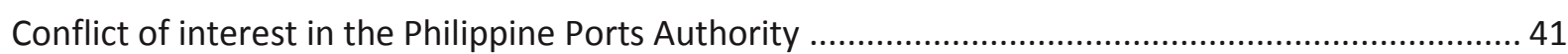

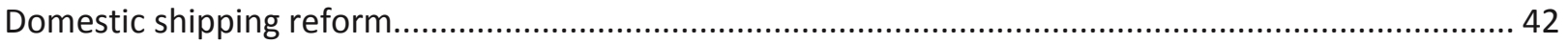

\footnotetext{
${ }^{1}$ This note was prepared by a team from the World Bank Group Trade and Competitiveness Global Practice Group led by Gerlin Catangui (Operations Officer), Lito Supangco (Consultant), Georgiana Pop (Economist, Competition Policy), Steve Meyrick (Consultant), Roberto Galang (Operations Officer), with valuable inputs from Martha Martinez Licetti (Senior Economist, Competition Policy) and Tania Begazo Gomez (Economist, Competition Policy). This report was prepared under the guidance of Hans Shrader (Trade and Competitiveness Global Practice).
} 


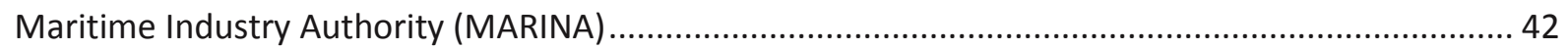

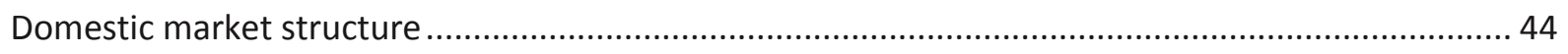

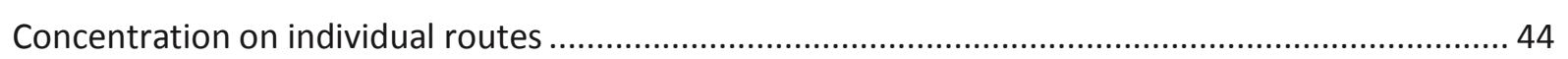

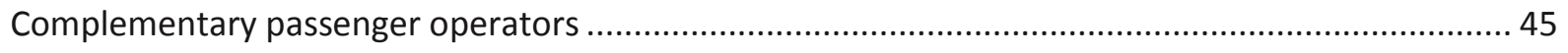

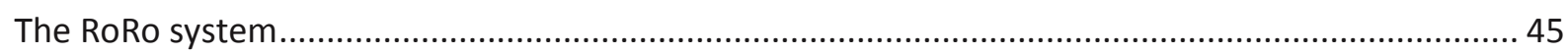

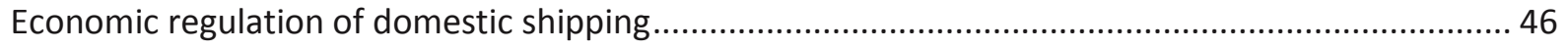

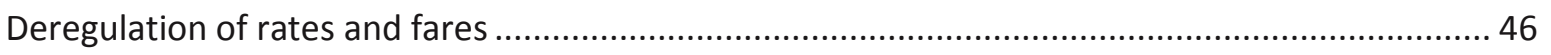

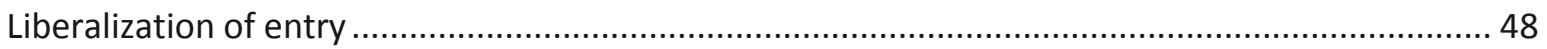

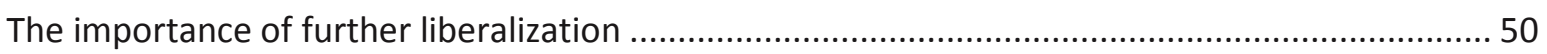

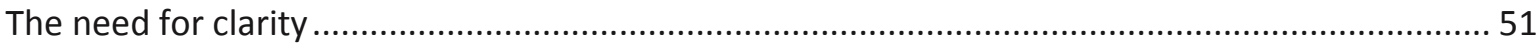

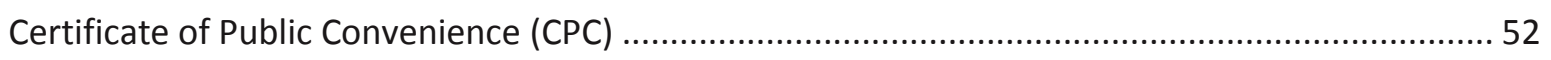

Chartering foreign vessels for deployment in the domestic routes ............................................. 57

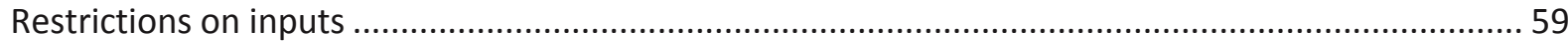

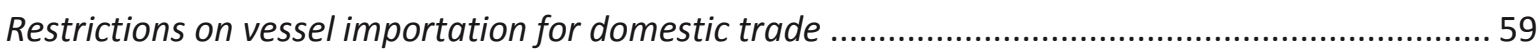

Requirement for drydocking of domestic vessels in domestic shipyards ........................................ 59

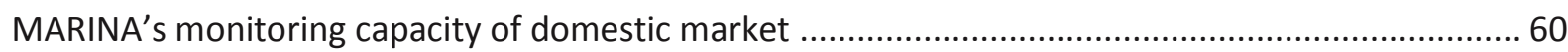

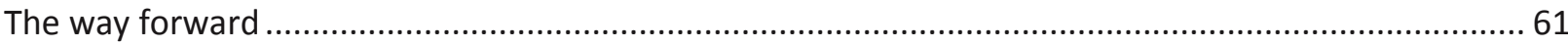

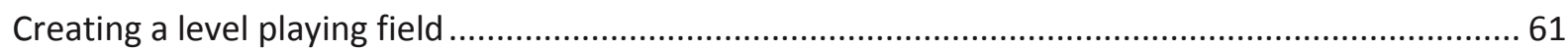

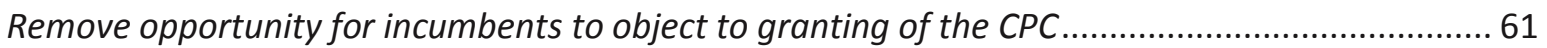

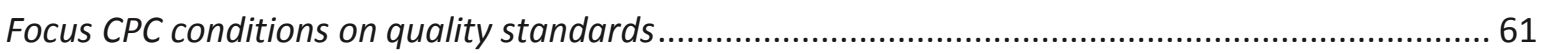

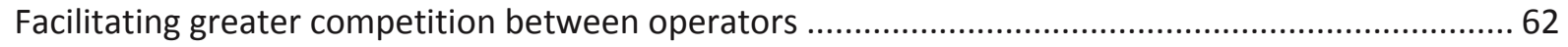

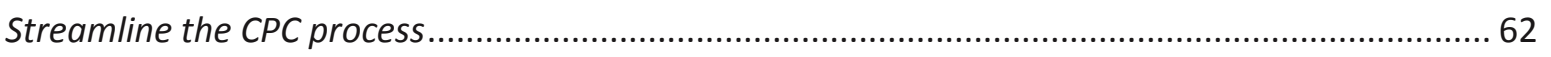

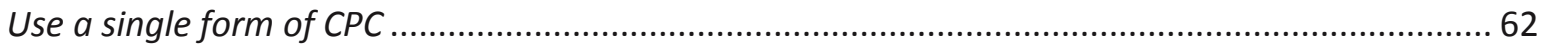

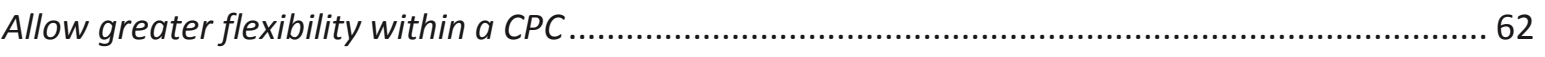

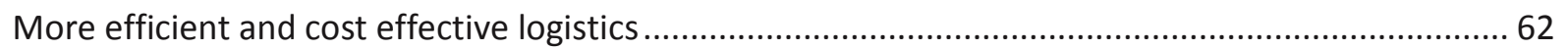

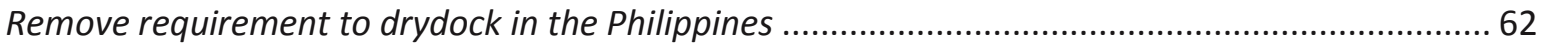

Remove restrictions on vessel importation for domestic trade ....................................................... 63

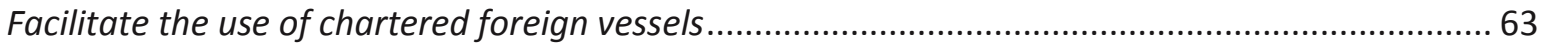

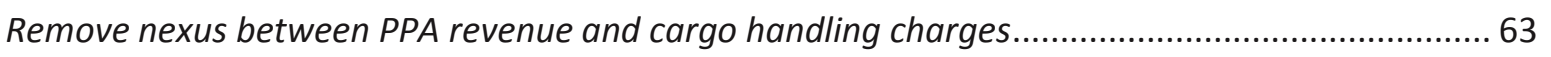

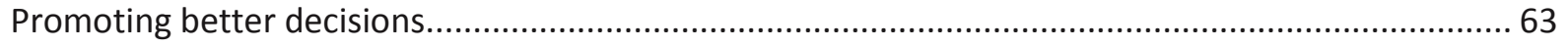

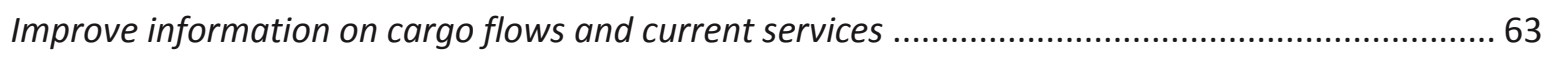

Freely disseminate information to actual and potential market participants .................................. 64

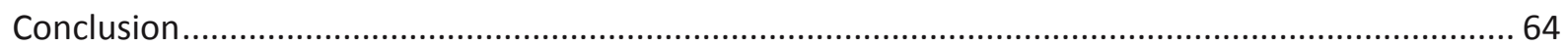




\section{Executive Summary}

\section{Introduction}

1. For the economy to attain its full potential, the Philippines requires an efficient water transport system. However, this is presently not the case. The domestic shipping industry is characterized by high costs, low quality of service, and a poor safety record. Logistics cost accounts for 24-53 percent of wholesale price, while shipping and port handling cost around 8 percent of wholesale price and 5 percent of retail price. ${ }^{2}$ Philippine domestic shipping is generally more expensive than in Malaysia or Indonesia-2 other archipelagos. Moreover, it is more expensive to transport goods between 2 Philippine ports than between 2 Philippine ports via an international port. In the East Asia region, the Philippines trails behind its neighbors in various logistics performance and connectivity indices. For instance, in liner shipping connectivity, the Philippines ranked $66^{\text {th }}$ out of 157 countries in 2013, and performs the worst among a group of East Asian comparators. ${ }^{3,4}$ Delays in shipment, slow cargo handling, and frequent accidents are the top complaints of businesses. In the East Asia Region, the Philippines has the highest absolute casualty rate and this is 40 percent higher than the second ranked country, Indonesia. ${ }^{5}$ On average, there are 228 ships involved in accidents and 303 casualties per year in the Philippines.

2. Among the probable causes of the poor state of the domestic shipping industry are the constraints on competition existing within the domestic shipping market. Removing competition constraints and enhancing competitiveness of shipping companies would result in greater efficiency, increased capacity, improved quality of ships, lower costs, and lower freight rates that would enhance the competitiveness of Philippine agricultural products.

3. However, intensifying competition does not necessarily imply more competitors on individual routes. In the Philippines, as in other countries, few operators serve most domestic shipping routes. Of the 54 primary routes for which data was obtained in this assessment, over 40 percent were served by a single operator. A further third were served by just 2 operators, and less than one quarter were served by 3 or more competitors.

4. This concentration is not surprising. There are 2 main characteristics of the industry that lead to this outcome:

\footnotetext{
${ }^{2}$ These prices are averages based on a sample of goods. See Tables 6 and 7 for a list of references for these goods.

${ }^{3}$ The Liner Shipping Connectivity Index captures how well countries are connected to global shipping networks. It is computed by the United Nations Conference on Trade and Development (UNCTAD) based on 5 components of the maritime transport sector: number of ships, their container-carrying capacity, maximum vessel size, number of services, and number of companies that deploy container ships in a country's ports.

${ }^{4}$ It can be argued that Philippine ships serving domestic routes are less efficient than Philippine ships serving international routes, given the high rate of maritime accidents and complaints from businesses. In this case, the liner shipping connectivity score for the Philippines provides an upper bound for the performance of domestic ships.

${ }^{5}$ The Philippines also has the highest relative casualty rate, surpassing Myanmar. This is measured by the ratio of total casualties to total fleet size.
} 
- There are significant economies of scale in ship operations: many cost items - such as construction costs, crewing, insurance and repair and maintenance costs - increase less than proportionately with vessel size.

- Frequency is an important aspect of the quality of service that a shipping company offers to its major customers. All other things being equal, a service that offers 2 sailings a week is likely to be more attractive to a potential customer - particularly a large shipper of perishable products - than a service offering only a single sailing.

A high degree of concentration on individual routes is therefore a natural consequence of market characteristics, and is unlikely to change.

5. Given relatively concentrated markets, the threat of potential entry is often the major force disciplining market behavior. Fortunately, natural barriers to entry in the shipping sector are relatively low. Although significant capital investment is required, the overwhelming majority of this investment is in the ships themselves. These assets are extremely mobile, and can be readily redeployed to another market if entry is unsuccessful. Also, for the most part, the technology used in the shipping industry is generic and readily available for potential new entrants.

6. For these reasons, in the absence of regulatory or legislative barriers, the threat of entry is likely to be real and constant. It is also likely to be effective in disciplining market behavior. This is because the stakes for the incumbent operator are very high. One consequence of concentration is that successful new entry may not mean that an incumbent simply loses market share; it may mean it is forced to abandon the market altogether, if the incumbent does not adjust their services.

7. In older regulatory regimes, such as that which existed in the Philippines prior to the passage of the Domestic Shipping Development Act of $2004^{6}$, this process was regarded as destructive competition. However, it is more appropriate, and more consistent with the deregulatory direction of the Domestic Shipping Development Act of 2004, to regard entry and exit as essential parts of the dynamics of the market. It is the means by which competition ensures that shipping lines operate efficiently and do not make excess profits.

8. In seeking to enhance competition in the delivery of domestic shipping services, this assessment has therefore focused particularly on measures that would increase the opportunities and incentives for new players to enter the market, and for existing operators to expand or vary the services they offer.

\section{The need for clarity and simplicity}

9. The stakeholder consultation process undertaken as part of this assessment revealed that

\footnotetext{
${ }^{6}$ Republic Act No. 9295, An Act Promoting the Development of Philippine Domestic Shipping, Shipbuilding, Ship Repair and Ship Breaking, Ordaining Reforms in Government Policies Towards Shipping in the Philippines, May 3 2004.
} 
the regulatory system is inconsistently understood. Amongst industry participants, there were, for example, differences of views on the criteria that applied to the issuance of a Certificate of Public Convenience (CPC), and what this implied for the ease (or otherwise) with which one could be obtained. There was uncertainty as to whether an operator who had received a CPC as a tramper vessel (that is, without specifying the intended route for the vessel) could then use that vessel to operate a scheduled service as a common carrier. There were different understandings of the conditions under which foreign registered vessels on charter to Filipino shipping companies could be used to provide domestic shipping services.

10. These regulatory uncertainties can in themselves constitute a barrier to entry. Potential new entrants face a lower business risk when the rules that apply in the target market, and the way in which they are applied, are clearly understood by all parties. Uncertainties tend to bias the market in favor of incumbents: where the rules are unclear, those who have been operating in the market for some time can draw on their experience of how things operate, while newcomers do not have this advantage. Improving clarity and certainty will therefore have a pro-competitive effect.

11. Improved communication can help, but the most powerful tool for improving understanding is simplification. Over time, most regulatory systems accrue rules, practices and procedures that may once have been necessary but which are no longer required or appropriate to current conditions. These historical accretions make the system more complex and less transparent than it need be. This appears to have happened in the case of the regulation of domestic shipping in the Philippines. Enhancing the competitive environment therefore requires a review of all regulations and practices that could - actually or potentially - restrict the flexibility of shipping lines to provide services wherever, whenever and (subject to safety and environmental constraints) with whatever ships they see a commercial opportunity to do so.

\section{Direction forward}

12. The key task in enhancing the competitiveness of domestic shipping is to ensure the effective operation in the market for shipping services. Many of the recommendations that follow therefore focus on measures that will serve to ensure that some market participants do not enjoy an unfair advantage over others, as well as measures that lower regulatory barriers to entry.

13. But improving competitiveness also requires reform of regulations that increase the costs faced by all shipping operators. The direction forward therefore includes recommendations to reform regulations and practices that raise, or may tend to raise, the costs faced by incumbents and new entrants alike. Since markets work more effectively when decisions are based on timely and accurate information, the direction forward also includes recommendations designed to improve the quality of information available to both regulators and market participants. 
14. Finally, successful implementation of the reforms is expected to generate an annual increase of at least USD 18 million in aggregate private sector investments. ${ }^{7}$ By eliminating the different regulatory barriers to investment in the shipping industry, the costs of entering and operating new shipping capacity becomes less prohibitive for the private sector. This should positively impact the profitability of shipping companies and lead to additional investment in new capacity by both new and existing firms.

\section{Creating a level playing field}

\section{Remove opportunity for incumbents to object to granting of the CPC}

15. Any person wishing to operate a commercial domestic shipping service in the Philippines must first obtain a Certificate of Public Convenience. The criteria that govern the issue of a $\mathrm{CPC}$, the process by which it is issued, and the conditions that are attached to it can therefore all affect the extent of effective competition in the shipping market.

16. In the present process, an application for a CPC to operate a new service can be challenged by an operator already providing services in the relevant market (based on the Maritime Industry Authority's (MARINA) implementing regulations). The incumbent operators can contest the feasibility study of the new applicant by arguing that the market is too small to accommodate an additional participant and that new entry would not be financially viable.

17. There is a range of views on whether this provision has, in practice, a substantial effect on the ease with which operators can introduce new services. But it clearly creates the possibility that an incumbent will use the process to delay the entry of a new competitor (as indicated by a small shipping operator); to add to the cost that the competitor faces in entering the market; and, in the extreme case, to block entry altogether. The process appears

\footnotetext{
${ }^{7}$ Removing barriers to entry in the shipping sector is expected to generate an expansion of business by existing shipping companies as well as the potential entry of new market players - these are assumed to increase competitive pressure and lead to lower freight rates and better quality of services. The effects of removing barriers to entry would be estimated on additional investment in the sector. In the Philippines, the six largest companies that transport containerized goods invest around \$36 million annually, given their evolution of fixed assets and assuming that the annual investment consists in the year-on-year difference in the stock of fixed assets plus the replacement of depreciating capital ( $8 \%$ depreciation rate). These companies capture about $88 \%$ of the market shares, so by extrapolating we assume that total investment in container ships is around $\$ 40$ million. Therefore there is an assumption of a reduction in per nautical miles freight rates of $20 \%$ due to increase competitive pressure. Price elasticity of demand for transport is assumed to be relatively low over four years - a price drop of $20 \%$ is assumed to increase demand for transport of containerized goods on domestic routes. The effects associated with removal of one of the barriers to entry (i.e., prior operator rule for the issuance of certificate of public convenience) are expected to: 1) facilitate the purchase and lease of newer vessels and younger vessels are more expensive and 2) give a one-off boost in the quality of ships (cold chain facilities etc.) when ships are renewed. According to local industry experts the average age of vessels is expected to fall by $10 \%$. Locally gathered data of the prices of 3500-5000 GRT geared ships that can transport containerized goods suggests that a $10 \%$ decrease of fleet age is associated with a $6 \%$ increase in the value of the vessel. According to the industry experts it is expected that such a reform provides a $2 \%$ one-off quality boost. Taking these two effects into account, the value of assets per metric ton transported would rise by $8 \%$ to $\$ 16.2$. The investment necessary to expand capacities to cover demand for transport of 1.1 million additional metric tons of containerized goods would therefore amount to $\$ 18$ million (over four years).
} 
to be a legacy of the period of regulated domestic shipping that preceded RA 9295.

18. RA 9295 is expressly deregulatory in intent ${ }^{8}$, and formally established the ability of domestic shipping operators to establish their own rates. It preserved the requirement that operators obtain a CPC, and that, in their application for a CPC, operators specify the service that they intend to provide. But it does not expressly require the MARINA to assess or form a judgment on the effect of granting the application on the viability of pre-existing services. Rather, insofar as it refers to the impact of the proposed service on third parties, the clear focus is on "the economic and beneficial effect, which the proposed services shall have to the port province or region which it proposes to serve".

\section{Focus CPC conditions on quality standards}

19. Effective competition in domestic shipping does require that all participants are held to the same safety and environmental standards. The process of issuing Certificates of Public Convenience can be a useful regulatory tool in ensuring that this condition is met. The intention that it should do so is clear in RA 9295, which requires that MARINA, in granting an application for a CPC, take into consideration, "the financial capacity of the domestic ship operator to provide and sustain safe, reliable, adequate, efficient and economic service". ${ }^{9}$

\section{Facilitating greater competition between operators}

\section{Streamline the CPC process}

20. The application process for a CPC is quite expensive for the applicant due to the application and other MARINA fees, publication requirements, and legal fees. Many of these steps are repetitive and may be further streamlined to minimize the processing time and costs for the issuance of the CPC.

21. Once the concept of objection by incumbents is eliminated from the process of awarding a CPC, there is no longer any need for an ex ante quasi-judicial process. This should facilitate a significant reduction in both the time and the cost involved in granting a CPC application, and help refocus MARINA's activities on ensuring that all participants are held to the same safety and environmental standards.

\section{Use a single form of CPC}

22. At present, CPCs are divided into "liner CPCs" and "tramper CPCs"; however, there does not appear to be any effective mechanism for preventing the holder of a tramper CPC from operating a regular scheduled service that provides cargo space to a variety of customers; that is, from operating a liner service. From an economic perspective, this is not a bad thing. Operators of tramp ships are an important source of potential new entry on liner routes, and allowing them to freely do so enhance the competitive environment. But there seems little to

\footnotetext{
${ }^{8}$ The Title of Chapter 3 of RA No. 9295 commences with the words "Deregulation of the domestic shipping industry".

${ }^{9}$ RA No. 9295, Section 7.
} 
be gained from continuing to formally distinguish between the 2 forms of CPC and the interests of clarity and certainty would be served by eliminating this distinction.

\section{Allow greater flexibility within a CPC}

23. In applying for a CPC, the shipping operator is required to specify the ships that it will use and the services that it will provide. Where the service is a liner service, this implies defining the route(s) on which the vessels will be deployed.

24. This practice places limits on the flexibility that an operator has in responding to market conditions by deploying vessels in other routes or replacing an existing vessel with another. As the CPC is issued to the operator, it is able to vary which of the vessels is assigned to which of the routes included on its CPC. But if the operator wishes to redeploy a vessel to a route not specified in the CPC, or to introduce a new vessel, it is necessary to obtain approval to amend the CPC.

25. In a market-based system, vessel deployment should be a management prerogative. Seeking approval imposes additional costs on the shipping operator, as, for each amendment to the CPC, MARINA imposes additional fees. This could be avoided while retaining the CPC framework, by allowing an operator, once it has been granted a CPC, to vary the routes and vessels covered by the CPC simply by providing notice to MARINA that it intends to make these changes, rather than seeking approval to make them.

\section{More efficient and cost effective logistics}

\section{Remove requirement to dry dock in the Philippines}

26. Current regulations require domestic vessels to undertake their dry docking and ship repair/maintenance requirements in domestic shipyards. This policy actually reduces the level of competition faced by domestic shipyards and increases the costs faced by domestic shipping operators.

27. Several private shipping companies consulted during the stakeholder engagement process indicated that, particularly for larger ships, they would prefer to have their ships dry docked and repaired in foreign shipyards, indicating that, for the largest vessels, savings of up to 50 percent of dry docking costs could be saved if this requirement were eliminated.

Remove restrictions on vessel importation for domestic trade

28. Current regulations impose restrictions on vessel importation for domestic trade. These laws require MARINA to evaluate and determine the capability of registered shipyards to build and construct new vessels for the domestic trade. If MARINA finds there to be domestic capability to meet domestic demand, all domestic ship operators are discouraged from importing new or previously owned vessels that are less than 500 GRT for the domestic trade. This policy reduces the ability of firms to source their vessels from the most efficient producer.

Allow approval for the chartering of foreign vessels to temporarily operate in domestic trade 
29. Shipowners' costs can be reduced by ensuring that they have ready access to the pool of vessels available on the global market. In many cases, this does not necessarily mean the outright purchase of a ship which could be costly upfront, but could also mean the leasing of a vessel for temporary use in the country.

30. It is possible for Filipino shipowners to temporarily operate a foreign-flagged vessel in the domestic trade if they obtain a permit to bareboat-charter the vessel. Such a mechanism allows domestic firms to lease a ship for a specific time period to test the feasibility of plying new routes or using new vessel types, without needing to shoulder the full costs of purchasing and importing the vessel outright.

31. While the chartering process could be further streamlined at MARINA, there is currently policy uncertainty with the Department of Finance (DOF) and the Bureau of Internal Revenue (BIR) as to the tax status of bareboat-chartered vessels. It had been standard practice in the Philippines to allow the tariff and duty-free entry of bareboat-chartered foreign vessels since the passage of PD760 in 1975, as long as the charter provides a re-export bond to ensure the departure of the vessel from the country at the end of the charter period.

32. Current charters are now subjected to the full tariff and VAT payments required of purchased vessels. There is a lack of a clear regulatory basis on said import status of bareboatchartered vessels, for which the DOF has decided to treat them as direct vessel importations.

33. The change in the tax status of bareboat chartering has limited the willingness of firms to charter vessels. In certain instances, it has become unfeasible to recover the additional taxes over the course of the limited charter period.

Remove nexus between Philippine Ports Authority (PPA) revenue and cargo handling charges

34. Under current administrative arrangements, PPA regulates the charges that are levied by cargo handling operators. But it is also a commercial beneficiary of increases in those rates: the PPA receives a 10 percent and a 20 percent share of the domestic and foreign cargo handling rates collected, respectively. This creates a conflict of interest for PPA.

35. It should be acknowledged that processes have been developed and adopted that provide opportunities for user input into decisions on cargo handling rates, and to increase transparency. These serve to mitigate the conflict of interest, and reduce the risk that it will lead to cargo handling charges that are unnecessarily high. But it would be better to eliminate the conflict altogether.

36. This could be done quite simply by changing the structure of the fee paid to PPA by cargo handling operators. Rather than setting this fee as a percentage of revenue, it could be specified as a fixed annual charge, or a fixed rate per unit of cargo handled. This would break the nexus between cargo handling charges and PPA revenue, and remove the perception and the risk - that PPA's regulatory decisions on cargo handling charges are influenced by its commercial interests. 


\section{Promoting better decisions}

\section{Improve information on cargo flows and current services}

37. While both MARINA and PPA collect information on the maritime transport system, information on cargo volumes and shipping services are not systematically compiled. Much of the data are captured at the regional level and are not consolidated to provide a systemwide snapshot of maritime operations.

38. Better information would be beneficial for a variety of regulatory and planning purposes. As the deregulation of the sector is pursued, a strong monitoring capability is necessary to detect and remedy market failures as they arise. But MARINA has a limited number of regional offices and does not have the resources to monitor all of the country's shipping routes. Its ability to monitor shipping operations in the whole country is compromised by the lack of comprehensive and timely information. Better-integrated information should also help support PPA in the execution of its planning functions and in monitoring the performance of particular service provides within its ports.

\section{Freely disseminate information to actual and potential market participants}

39. Competition will be more effective if the basis on which the decision of individual market participants is better. It is not only public sector agencies that are likely to benefit from improved information. To some extent, commercial operators have an incentive to gather such information themselves, and are likely to do so. But this is costly and wasteful - and it often functions as a barrier to entry, since incumbents have the greater opportunity to assemble privately held information on market opportunities. For the greatest benefit to be derived from investments in maritime data collection, it is important that this data is - to the extent consistent with commercial confidentiality — made widely available.

\section{Summary of recommendations}

40. The recommended policy actions arising from the assessment are summarized in Table 1 below. 
Table 1: Summary of recommended actions

\begin{tabular}{|c|c|c|c|c|}
\hline Reform Objectives & Proposed Action & Justification & Potential Risks & Required Action \\
\hline $\begin{array}{l}\text { Creating a level } \\
\text { playing field }\end{array}$ & $\begin{array}{l}\text { Remove opportunity for } \\
\text { incumbents to object to } \\
\text { granting of CPC }\end{array}$ & $\begin{array}{l}\text { Opportunity for } \\
\text { incumbents to object adds } \\
\text { to cost of new entry and } \\
\text { provides potential to delay } \\
\text { or block entry in the } \\
\text { interests of existing } \\
\text { operators. }\end{array}$ & $\begin{array}{l}\text { May facilitate the entry of } \\
\text { shipping firms that are not } \\
\text { properly assessed by the } \\
\text { regulator in terms of } \\
\text { quality and safety } \\
\text { standards }\end{array}$ & $\begin{array}{l}\text { Amend MARINA MC No. } \\
\text { 74; IRR of RA No. } 9295\end{array}$ \\
\hline $\begin{array}{l}\text { Facilitating greater } \\
\text { competition between } \\
\text { operators }\end{array}$ & $\begin{array}{l}\text { Streamline the CPC } \\
\text { process }\end{array}$ & $\begin{array}{l}\text { Slow, uncertain and/or } \\
\text { costly CPC processes can } \\
\text { act as deterrent to entry. }\end{array}$ & & $\begin{array}{l}\text { Adopt a Memorandum } \\
\text { Circular amending MARINA } \\
\text { MC No. } 169 \text { of } 2001 \text { and } \\
\text { MC No. } 74\end{array}$ \\
\hline
\end{tabular}


Working paper for comments and subject to change.

\begin{tabular}{|c|c|c|c|c|}
\hline Reform Objectives & Proposed Action & Justification & Potential Risks & Required Action \\
\hline & Use a single form of CPC & $\begin{array}{l}\text { Current distinction } \\
\text { between tramp and liner } \\
\text { operators suggests a } \\
\text { market division that is } \\
\text { neither desirable nor } \\
\text { sustainable. This would } \\
\text { imply removal of route } \\
\text { definitions from CPC. }\end{array}$ & $\begin{array}{l}\text { May facilitate the exit of } \\
\text { firms from underserved } \\
\text { routes }\end{array}$ & $\begin{array}{l}\text { Amend MARINA MC No. } \\
169 \text { of } 2001 \text { and MC No. } 74\end{array}$ \\
\hline & $\begin{array}{l}\text { Allow greater flexibility } \\
\text { within a CPC }\end{array}$ & $\begin{array}{l}\text { Competition will be } \\
\text { enhanced if accredited } \\
\text { operators have full } \\
\text { flexibility to respond to } \\
\text { emerging market } \\
\text { conditions. }\end{array}$ & $\begin{array}{l}\text { May create greater } \\
\text { volatility in the schedule of } \\
\text { shipping services }\end{array}$ & $\begin{array}{l}\text { Amend MARINA MC No. } \\
169 \text { of } 2001 \text { and MC No. } 74\end{array}$ \\
\hline $\begin{array}{l}\text { More efficient and } \\
\text { cost effective logistics }\end{array}$ & $\begin{array}{l}\text { Remove regulatory } \\
\text { barriers to vessel } \\
\text { importation }\end{array}$ & $\begin{array}{l}\text { Eliminating this } \\
\text { requirements will increase } \\
\text { access to alternative } \\
\text { vessels (below } 500 \text { GRT) } \\
\text { suppliers }\end{array}$ & $\begin{array}{l}\text { May lead to a decrease in } \\
\text { income by the national ship } \\
\text { building sector }\end{array}$ & $\begin{array}{l}\text { Amend Section 20: } \\
\text { Restrictions on Vessel } \\
\text { Importation of RA No. } 9295\end{array}$ \\
\hline
\end{tabular}


Working paper for comments and subject to change.

\begin{tabular}{|c|c|c|c|c|}
\hline Reform Objectives & Proposed Action & Justification & Potential Risks & Required Action \\
\hline & $\begin{array}{l}\text { Facilitate approval for the } \\
\text { bareboat-chartering of } \\
\text { foreign vessels to } \\
\text { temporarily operate in } \\
\text { domestic trade }\end{array}$ & $\begin{array}{l}\text { Restrictions on the use of } \\
\text { chartered vessels limit } \\
\text { flexibility in operation and } \\
\text { acts as a drag on } \\
\text { innovation. }\end{array}$ & & $\begin{array}{l}\text { Revise MC No. 2011-04, MC } \\
\text { 182. Clarify with DOF/BIR } \\
\text { on rules pertaining to } \\
\text { taxation of bareboat } \\
\text { chartered vessels }\end{array}$ \\
\hline & $\begin{array}{l}\text { Remove nexus between } \\
\text { PPA revenue and cargo } \\
\text { handling charges }\end{array}$ & $\begin{array}{l}\text { PPA receives a percentage } \\
\text { of cargo handling fees, } \\
\text { giving rise to real or } \\
\text { perceived conflict of } \\
\text { interest. }\end{array}$ & & Amend LOI No. 1005-A \\
\hline $\begin{array}{l}\text { Promoting better } \\
\text { decisions }\end{array}$ & $\begin{array}{l}\text { Improve information on } \\
\text { cargo flows and current } \\
\text { services }\end{array}$ & $\begin{array}{l}\text { Effective regulation and } \\
\text { planning requires accurate } \\
\text { information. } \\
\text { Comprehensive } \\
\text { information is currently } \\
\text { collected via manifests and } \\
\text { ship call reports but it is not } \\
\text { assembled or analyzed in a } \\
\text { way that allows meaningful } \\
\text { appraisal of market } \\
\text { conditions. }\end{array}$ & $\begin{array}{l}\text { May allow firm access to } \\
\text { critical competitive } \\
\text { information that lowers } \\
\text { competition in the sector }\end{array}$ & $\begin{array}{l}\text { Develop centralized } \\
\text { database of port level } \\
\text { statistics. } \\
\text { Develop indicators for } \\
\text { maritime sector } \\
\text { performance (e.g. service } \\
\text { reliability, berth utilization). }\end{array}$ \\
\hline
\end{tabular}


Working paper for comments and subject to change.

\begin{tabular}{|l|l|l|l|l|}
\hline Reform Objectives & \multicolumn{1}{|c|}{ Proposed Action } & \multicolumn{1}{c|}{ Justification } & \multicolumn{1}{c|}{ Potential Risks } & Required Action \\
\hline & $\begin{array}{l}\text { Freely disseminate } \\
\text { information to actual and } \\
\text { potential market } \\
\text { participants }\end{array}$ & $\begin{array}{l}\text { Better information on } \\
\text { market conditions reduces } \\
\text { direct costs for operators, } \\
\text { and facilitates better } \\
\text { decisions on when and how } \\
\text { to enter markets. }\end{array}$ & & $\begin{array}{l}\text { Provide web-based access } \\
\text { to data on maritime market } \\
\text { activity. }\end{array}$ \\
& & & & \\
\hline
\end{tabular}




\section{Introduction}

43. The World Bank Group Trade and Competitiveness Global Practice Group is implementing a multi-year program focused on improving the productivity and competitiveness of Filipino farmers and agribusiness as a means of contributing to the sustainable economic development of rural Philippines. The program involves 3 interrelated components which address system challenges to the competitiveness of Philippine agribusiness, including low farmer productivity and poor access to infrastructure, poor farmer access to finance and high transaction and compliance costs. The objectives of the program include:

- Improved gross margins for smallholder farmers by raising their performance in partnership with large "lead firm" agribusiness to create or improve supply chain models that can meet market and customer requirements on a sustainable basis;

- Increased investments in agriculture and the agribusiness sector by providing advisory services to select Philippine financial institutions to help them better meet agribusiness and farmer's financing needs through traditional lending mechanisms and the development and application of new financial products; and

- Reduced compliance and transaction costs for farmers and the agribusiness sector by addressing regulatory and competition constraints in the agriculture supply chains around trade, transport and logistics and warehousing regulations

44. In response to the World Bank Group-wide priority to address food security concerns, the Trade and Competitiveness Practice Group has committed to ramp up assistance in investment generation for the agribusiness sector. Agribusiness is a critical sector of the Philippines' economy. It accounts for 18 percent of GDP and employs over 11.5 million people accounting for almost 35 percent of the workforce. If the entire agribusiness value chain is considered, its contribution to GDP reaches 35 percent and one half of all working Filipinos are employed by the sector. While the sector is critical to livelihoods and poverty alleviation, the sector is underperforming. Growth has declined from 4.9 percent in 2007 to negative 0.5 percent in 2010 while employment levels remained relatively steady. Productivity of the workforce has moved up by a modest 1.7 percent since 2004 but yield of traditional crops have stagnated or declined and comparative advantages in key crops are not being sufficiently exploited - the Philippines' share and value of exports is among the lowest in comparable ASEAN countries. The sector's underperformance coupled with its importance indicates considerable potential for improved contribution to inclusive economic growth, rural development, and poverty reduction.

45. Transport and logistics are key inputs to the agriculture value chains and contribute to food prices. Because of the nation's archipelagic geography, transport and agricultural markets are linked together, as parts of a single joint production function. Supply chain infrastructure and service limitations at the supply end of food chains directly affect the timeliness, quality and price of food products delivered at the demand end. Clearly, interisland transport systems that fairly and efficiently facilitate the flow of agricultural products and related inputs are becoming increasingly important. 
46. The Government of the Philippines (GoP) recognizes these issues and is working to address them through various policy and support programs. For example, the Philippine Development Plan (PDP) 2011-2016 reaffirms the importance of agricultural development to inclusive growth in recognition of its contribution to output and employment. However, an area the private sector regularly identifies as a critical area of reform but is not well addressed is improved efficiency in trade and logistics, which is relevant given the amount of food being shipped from Mindanao to the larger urban centers. For this reason, this study seeks to understand a number of agri-trade regulatory constraints, as well as competition constraints that affect the domestic shipping industry in targeted jurisdictions to enable commercial smallholders' improved market access and integration.

\section{Indicators of competitiveness}

47. The Philippine Development Plan $2011-2016^{10}$ highlights the need for the agriculture sector to become more competitive. In the 2012-13 Global Competitiveness Index (GCI) of the World Economic Forum, the Philippines ranked $65^{\text {th }}$ of 144 countries for which data was available (up from $75^{\text {th }}$ of 142 countries included in 2010-11).

48. Transport infrastructure and services perform a vital role in the agriculture supply chain. Table 2 compares the infrastructure quality index, which forms part of the Global Competitiveness Index, for 9 ASEAN and South Asian countries. The Philippines ranked $8^{\text {th }}$ of 9 countries in the overall quality of its infrastructure (98th out of 144 countries surveyed) and very poorly in the quality of the port infrastructure (ranked $120^{\text {th }}$ out of the 144 countries surveyed).

49. What is clear from the table is that infrastructure quality in general, and the quality of port infrastructure in particular, acts as a drag on the competitiveness of the Philippines: on these specific dimensions of competitiveness, the Philippines ranks much lower than it does on the general competitiveness index.

Table 2: Ranking of the Philippines in the Global Competitiveness Index

\begin{tabular}{|c|c|c|c|c|c|c|c|c|}
\hline \multirow[t]{2}{*}{ Country } & \multicolumn{2}{|c|}{ Overall Rank } & \multicolumn{2}{|c|}{ GCI Score } & \multicolumn{2}{|c|}{$\begin{array}{c}\text { Quality of } \\
\text { Infrastructure }\end{array}$} & \multicolumn{2}{|c|}{$\begin{array}{l}\text { Quality of Port } \\
\text { Infrastructure }\end{array}$} \\
\hline & $\begin{array}{c}2011- \\
2012\end{array}$ & $\begin{array}{l}2012- \\
2013\end{array}$ & $\begin{array}{c}2011- \\
2012\end{array}$ & $\begin{array}{c}2012- \\
2013\end{array}$ & $\begin{array}{c}2010- \\
2011\end{array}$ & $\begin{array}{c}2012- \\
2013\end{array}$ & $\begin{array}{c}2010- \\
2011\end{array}$ & $\begin{array}{r}2012- \\
2013\end{array}$ \\
\hline Malaysia & 21 & 25 & 5.1 & 5.1 & 5.7 & 5.4 & 5.7 & 5.5 \\
\hline Brunei & 27 & 28 & 4.8 & 4.9 & 5.0 & 5.1 & 4.4 & 4.5 \\
\hline Thailand & 39 & 38 & 4.5 & 4.5 & 4.7 & 4.9 & 4.7 & 4.7 \\
\hline Indonesia & 46 & 50 & 4.4 & 4.4 & 3.9 & 3.7 & 3.6 & 3.6 \\
\hline Vietnam & 65 & 75 & 4.2 & 4.1 & 3.1 & 3.2 & 3.4 & 3.4 \\
\hline Sri Lanka & 52 & 68 & 4.3 & 4.2 & 4.7 & 4.8 & 4.9 & 4.9 \\
\hline Philippines & 75 & 65 & 4.1 & 4.2 & 3.4 & 3.6 & 3.0 & 3.3 \\
\hline
\end{tabular}

\footnotetext{
${ }^{10}$ National Economic Development Authority, 2011. Philippine Development Plan 2011-2016, National Economic Development Authority, Pasig.
} 
Working paper for comments and subject to change.

\begin{tabular}{lcccccccc} 
Cambodia & 97 & 84 & 3.9 & 4.0 & 4.1 & 4.2 & 4.0 & 4.2 \\
Bangladesh & 108 & 118 & 3.7 & 3.7 & 2.8 & 2.8 & 3.4 & 3.3 \\
\hline
\end{tabular}

Source: Klaus Schwabb (ed) 2010, The Global Competitiveness Report 2010-11, World Economic Forum, Geneva.Klaus Schwabb (ed) 2012, The Global Competitiveness Report 2012-13, World Economic Forum, Geneva.

50. The insights of the $\mathrm{GCl}$ are supported by more specific analysis. The PDP and sector studies $^{11}$ identified many specific constraints on the competitiveness of the agricultural sector including:

- Declining productivity

- Fragmentation of the farm sector;

- Concentration of public support to rice production;

- High input costs (such as seed, fertilizer, crop protection, machineries);

- Limited access to appropriate inputs;

- Insufficient research and development;

- Inadequate farmer-support services such as post-harvest facilities; and

- Inefficient domestic transport

51. In the transport sector, and in the shipping industry in particular, several shortcomings were found to affect agriculture value chains, notably:

- Inadequate port and vessel capacities;

- Ineffective port management and administration; and

- Anti-competitive shipping policies and regulations

\section{Objective of the study}

52. To review options for improving the performance of the agribusiness sector through enhanced competitiveness of the transport sector, the World Bank Group Trade and Competitiveness Global Practice Group conducted an assessment aiming at identifying key competition constraints to maritime transport and transport services with a focus on interisland shipping. The recommendations and collected information are important inputs to the World Bank Group's Agricultural Trade Logistics Competitiveness project, which aims to help the GoP address trade logistics and transport constraints for commercial smallholders' improved market access and integration. It also forms one of the legs of the WBG's Shipping and Ports reform agenda.

53. The goal of this 4-year project is to help the GoP achieve its objective to diversify its agri-fisheries exports and ensure connectivity of farmers/ agribusiness to local, regional and global markets. The objective is to enhance agri-trade connectivity through coordination, transparency and predictability through focused interventions at-the-border and behind-theborder. The project also supports improvements in the regulatory framework of the

\footnotetext{
11 “Study on Agribusiness, Infrastructure and Logistics for Growth in Mindanao," World Bank 31 December 2010.
} 
domestic shipping market as a fundamental preparation for a more competitive environment that makes trade easier, less costly and more efficient based on transparency, predictability, non-discrimination of market players and simplification.

\section{Methodology}

54. The report builds on a number of studies and papers that have been produced, presented and discussed over the years. These past studies and papers were reviewed, serving as initial building blocks to the study (see Annex B for details). To explore the continuing relevance of the issues raised in these papers, and to develop a comprehensive understanding of the various issues, the team conducted interviews on main competition issues in the shipping sector with various stakeholders including international development institutions, government agencies/public officials, shipping and non-shipping corporations, non-government organizations, World Bank Group experts, and industry associations. In addition, information was collected based on the checklist on competition in transport services developed by the World Bank Group Competition Policy Team around 8 components:

- Market structure of transportation services;

- Direct state control over business enterprises;

- Market behavior and outcomes;

- Entry regulation;

- Price controls;

- Sector-specific regulations;

- State aids and subsidies; and

- Unequal treatment of market participants

55. The report aims to achieve a clear and balanced understanding of subsector issues by taking into account both previous reports and stakeholder interviews/data collection. The focus of the study is on the key issues that affect competition in shipping and port services and crosscutting issues that affect both subsectors. 


\section{Inefficiencies in the Philippine shipping industry}

\section{Significance of the industry}

56. The Philippine ports and shipping sectors account for a very small share of GDP and employment. Between 2008 and 2013, the 2 sectors account for only 0.2 percent of gross value-added. Average growth was slower at 3.9 percent compared to the economy-wide growth of 4.8 percent (Table 3). In 2010, employment in these sectors was estimated at around 54,000 (57,000 in 2013), of which around 18,000 are formally employed (Table 4). ${ }^{12}$

Table 3. GDP and sector performance

\begin{tabular}{|c|c|c|c|c|c|c|c|}
\hline & 2008 & 2009 & 2010 & 2011 & 2012 & 2013 & Average \\
\hline \multicolumn{8}{|l|}{ Share to total real GDP (\%) } \\
\hline GDP & 100 & 100 & 100 & 100 & 100 & 100 & 100 \\
\hline Services & 55 & 56 & 56 & 56 & 57 & 57 & 56 \\
\hline Transportation, Storage and Communication & 8.1 & 8.0 & 7.5 & 7.5 & 7.6 & 7.5 & 7.7 \\
\hline Water Transport & 0.3 & 0.2 & 0.2 & 0.2 & 0.2 & 0.2 & 0.2 \\
\hline \multicolumn{8}{|l|}{ Growth rate (\%) } \\
\hline GDP & & 1.1 & 7.6 & 3.6 & 6.8 & 7.2 & 5.3 \\
\hline Services & & 3.4 & 7.2 & 4.9 & 7.6 & 6.9 & 6.0 \\
\hline Transportation, Storage and Communication & & -0.1 & 1.0 & 4.3 & 8.1 & 5.6 & 3.8 \\
\hline Transportation & & -1.9 & -0.6 & 4.8 & 7.8 & 5.8 & 3.2 \\
\hline Water Transport & & -20.0 & 11.6 & 11.7 & 12.1 & -0.9 & 2.9 \\
\hline
\end{tabular}

Source: Philippine Statistics Authority

Table 4. Employment

\begin{tabular}{|c|c|c|c|c|c|c|c|}
\hline & \multicolumn{6}{|c|}{ LFS } & \multirow{2}{*}{$\begin{array}{c}\text { ASPBI } \\
2010\end{array}$} \\
\hline & 2008 & 2009 & 2010 & 2011 & 2012 & 2013 & \\
\hline \multicolumn{8}{|l|}{ Employment (in thousands) } \\
\hline Services & 17,196 & 18,111 & 18,873 & 19,722 & 19,740 & 20,141 & 2,609 \\
\hline Transportation, Storage and Communication & 2,595 & 2,685 & 2,726 & 2,779 & 2,805 & 2,875 & 255 \\
\hline Transport & 2,171 & 2,234 & 2,276 & 2,326 & 2,529 & 2,637 & 138 \\
\hline Water Transport & 52 & 51 & 54 & 56 & 55 & 57 & 18 \\
\hline Total & 34,088 & 35,062 & 36,034 & 37,191 & 37,558 & 38,050 & 3,966 \\
\hline \multicolumn{8}{|l|}{ Share to total employment (\%) } \\
\hline Services & 50.4 & 51.7 & 52.4 & 53.0 & 52.6 & 52.9 & 65.8 \\
\hline Transportation, Storage and Communication & 7.6 & 7.7 & 7.6 & 7.5 & 7.5 & 7.6 & 6.4 \\
\hline Transport & 6.4 & 6.4 & 6.3 & 6.3 & 6.7 & 6.9 & 3.5 \\
\hline Water Transport & 0.2 & 0.1 & 0.2 & 0.2 & 0.1 & 0.1 & 0.4 \\
\hline
\end{tabular}

57. Yet, the efficiency of ports and shipping operations has a significant impact on prices and jobs, given the archipelagic geography of the country. For instance, around 15 million agriculture workers in the Philippines depend on these 2 industries to connect to markets and sell their produce. In the Visayas, 18 million people rely on shipping to access the majority of

\footnotetext{
${ }^{12}$ Total employment is based on the 2010 Labor Force Survey while formal employment is based on the 2010 Annual Survey of Philippine Business and Industry.
} 
their goods, including food. In Mindanao, 22 million people rely on shipping for most manufactured goods given its trivial manufacturing sector. Its farmers also rely on shipping to bring their produce to Manila and to the rest of the world.

58. Currently, the maritime industry is beset with a number of inefficiencies. These are the high cost of shipping, low quality of service, and a poor safety record that manifests in frequent maritime accidents. These issues strongly suggest that the liberalization of the industry, which started in 1989, has yet to result in more efficiency and greater innovation in the industry. Box 1 discusses liberalization in the domestic shipping industry.

\section{Box 1. Liberalization of the domestic shipping industry}

\section{Pre-reform regulatory framework}

Regulation of the domestic shipping industry was first introduced during the American colonial period and was patterned after the US Jones Act and the Passenger Vessels Services Act. This sought to balance 2 objectives: protect the public from exorbitant tariffs and prevent "ruinous" competition among shipping operators. The Board of Transportation (BOT) was initially charged with regulating the industry, which covers route entry and tariff determination, until the creation of the Maritime Industry Authority (MARINA) in $1985 .{ }^{13}$

Between 1928 and 1985, the basic structure of tariffs remained largely unchanged. ${ }^{14}$ Tariffs were adjusted periodically and across-the-board for inflation. Upward adjustments were also made using the revenue deficiency method, which determined the tariff needed to provide a rate of return ${ }^{15}$ (ROI) consistent with the Public Service Act of 1936 (Commonwealth Act No. 146).

The shipping industry was initially exempted from government regulation requiring operators of all public services to obtain a certificate of public convenience (CPC). ${ }^{16}$ Route licensing was introduced in 1972. It restricted competition to prevent "overtonnage" on major routes and ensure the availability of service for the smaller and less lucrative routes. ${ }^{17}$

\footnotetext{
${ }^{13}$ MARINA was created under Presidential Decree No. 474 and mandated to provide effective supervision, regulation, and rationalization of the organizational management, ownership, and operations of all water transport utilities, and other maritime enterprises.

${ }^{14}$ See Renardet Sauti Consulting Engineers (1986) for more discussion.

${ }^{15}$ The maximum allowable ROI for public utilities has always been 12 percent.

${ }^{16}$ The Public Service Act stipulates in Section 13 (a) that "the Public Service Commission shall have no authority to require steamboats, motor ships and steamship lines, whether privately-owned, or owned or operated by any Government controlled corporation or instrumentality, to obtain certificate of public convenience or to prescribe their definite routes or lines of service."

${ }^{17}$ See Nathan Associates (1991) for more discussion.
} 


\section{Liberalization}

Beset with large-scale inefficiencies in the industry and frequent maritime accidents, the government embarked on a gradual liberalization of the industry beginning in 1989 . The setting of both passenger and freight tariffs, as well as routes, was gradually and partially liberalized.

The liberalization of tariffs began with the removal of ad valorem charges on passenger tariffs. In 1990, the 30 percent valuation surcharge for insurance premiums was abolished and freight tariffs for refrigerated cargoes, transit cargoes, and livestock were liberalized. In 1992, freight tariffs for Class A and Class B cargoes were liberalized. ${ }^{18}$ Through Executive Order 213 of 1994, all freight tariffs were liberalized except for non-containerized basic commodities. Full tariff liberalization was achieved in 1999 with the abolition of the Domestic Shipping Consultative Councils (DOSCONs), allowing shipping operators to fully set their own tariffs. ${ }^{19}$

In 1992, route liberalization was introduced through Memorandum Circular Nos. 71 and $\mathbf{8 0}$, which opened routes to at least 2 operators. Protection for developmental routes (i.e., low volume routes) was limited to a maximum of 5 years after which the route was opened to other operators. ${ }^{20}$ Executive Order 185 of 1994 further strengthened liberalization efforts by allowing operators to charge market-accepted freight and passage rates different from the fork rates (i.e., indicative or reference rates provided by MARINA) upon their provision of pioneering technological innovation of shipping service in a developmental route.

\section{Selected references}

Aldaba, R. 2008. "Assessing Competition in Philippine Markets." Philippine Institute for Development Studies Discussion Paper Series No. 2008-23.

Austria, M. 2002. "Philippine Domestic Shipping Industry: State of Competition and Market Structure." Philippine APEC Study Center Network Discussion Paper No. 2002-04.

\section{High cost of shipping}

59. Domestic shipping costs per mile are high. On average, Philippine shipping cost is significantly more expensive than Indonesia and slightly more expensive than Malaysia. The

\footnotetext{
${ }^{18}$ Class A cargo includes processed goods or high value manufactured goods. Class B cargo includes semiprocessed goods or low value manufactured goods.

${ }^{19}$ Prior to 1999, shipping operators were not allowed to determine their own tariffs. Instead, tariffs were negotiated through the Domestic Shipping Consultative Councils (DOSCONs), which was composed of shippers/consumers, operators, and government representatives.

${ }^{20}$ Before deregulation, protection was granted for an indefinite period (i.e., until the initial investment is recovered).
} 
average port-to-port cost per nautical mile in the Philippines is USD 1.47, higher than Indonesia's USD 0.77 and slightly higher than Malaysia's USD 1.36 (Table 5). ${ }^{21}$

Table 5. Domestic shipping cost in the Philippines, Indonesia, and Malaysia

\begin{tabular}{|c|c|c|c|c|c|c|c|c|c|c|}
\hline \multirow[b]{2}{*}{ Origin } & \multirow[b]{2}{*}{ Destination } & \multicolumn{4}{|c|}{ Cost } & \multirow[b]{2}{*}{$\begin{array}{l}\text { Destination port } \\
\text { domestic } \\
\text { throughput (MT) }\end{array}$} & \multicolumn{4}{|c|}{ Freight cost per NM } \\
\hline & & $\begin{array}{l}\text { Door to door (local } \\
\text { currency) }\end{array}$ & $\begin{array}{l}\text { Door to door } \\
\text { (USD) }\end{array}$ & $\begin{array}{l}\text { Port to port (local } \\
\text { currency) }\end{array}$ & $\begin{array}{l}\text { Port to port } \\
\text { (USD) }\end{array}$ & & Distance (NM) & Door to door & Port to port & $\begin{array}{l}\text { Number of } \\
\text { operators }\end{array}$ \\
\hline \multicolumn{11}{|l|}{ Malaysia } \\
\hline Kuala Lumpur & Kuching & 5,126 & 1,589 & 3,626 & 1,124 & $9,188,635$ & 653 & 2.43 & 1.72 & NA \\
\hline Kuala Lumpur & Kota Kinabalu & 5,756 & 1,784 & 3,976 & 1,233 & & 1005 & 1.78 & 1.23 & NA \\
\hline \multirow[t]{2}{*}{ Kuala Lumpur } & Sandakan & 6,176 & 1,915 & 4,576 & 1,419 & & 1250 & 1.53 & 1.13 & NA \\
\hline & & & & & & & & 1.91 & 1.36 & NA \\
\hline \multicolumn{11}{|l|}{ Philippines } \\
\hline Manila & Cebu & 36,000 & 827 & 26,150 & 600 & $18,169,471$ & 404 & 2.05 & 1.49 & 4 \\
\hline Manila & Cagayan do Oro & 38,000 & 873 & 28,495 & 654 & 6,171,957 & 504 & 1.73 & 1.30 & 5 \\
\hline Manila & Davao & 44,000 & 1,010 & 33,320 & 765 & $4,081,487$ & 829 & 1.22 & 0.92 & 5 \\
\hline Manila & Iloilo & 42,000 & 964 & 33,320 & 765 & $3,516,048$ & 355 & 2.72 & 2.15 & 4 \\
\hline Average & & & & & & & & 1.93 & 1.47 & \\
\hline \multicolumn{11}{|l|}{ Indonesia } \\
\hline Jakarta & Pontianak & $12,250,000$ & 1,065 & $5,000,000$ & 435 & $46,546,000$ & 420 & 2.54 & 1.04 & NA \\
\hline Jakarta & Makassar & $9,500,000$ & 826 & $5,300,000$ & 461 & $11,335,000$ & 762 & 1.08 & 0.60 & NA \\
\hline Jakarta & Banjarmasin & $10,500,000$ & 913 & $6,300,000$ & 548 & $7,642,000$ & 579 & 1.58 & 0.95 & NA \\
\hline Jakarta & Medan & $9,500,000$ & 826 & $6,000,000$ & 522 & $7,303,000$ & 861 & 0.96 & 0.61 & NA \\
\hline Jakarta & Balikpapan & $12,250,000$ & 1,065 & $5,800,000$ & 504 & $2,841,000$ & 765 & 1.39 & 0.66 & NA \\
\hline Average & & & & & & & & 1.51 & 0.77 & NA \\
\hline
\end{tabular}

60. Ironically, it is more expensive to transport goods between $\mathbf{2}$ domestic points than $\mathbf{2}$ domestic points via an international point. For example, transporting goods in a 40 -foot container from Manila to Cagayan de Oro costs some USD 1,860 but transporting between Manila and Cagayan de Oro via Kaohsiung would reduce the tariff by USD 716 to only USD 1,144 (Table 6). Moreover, a comparison of shipping costs in selected domestic and international routes indicates that domestic routes are more expensive than international routes on a per mile basis. For instance, the shorter Manila-Davao route is more expensive than the longer Hong Kong, Bangkok, and Port Klang to Manila routes (Table 7).

\footnotetext{
${ }^{21}$ These estimates are based on the average of available data. One issue with these estimates is that they do not compare the same products. A better approach would be to acquire the shipping costs of multinational companies, such as Nestle or Unilever, that are present in the Philippines, Malaysia, and Indonesia, for the same product. This could form part of future analysis.
} 
Table 6. Cost of shipping between 2 domestic points and 2 domestic points via an international point

\begin{tabular}{cccc}
\hline \multicolumn{4}{c}{ Cost (in USD) of domestic shipping vs. Foreign transhipment } \\
\hline $\begin{array}{c}\text { Type of shipping } \\
\text { container }\end{array}$ & Manila-Cagayan de Oro & Manila-Hong Kong-Cagayan de Oro & Difference \\
20 Footer & 1120 & 644 & 476 \\
40 Footer & 1860 & 1144 & 716 \\
& Manila-Cagayan de Oro & Manila-Kaohsiung-Cagayan de Oro & Difference \\
20 Footer & 1120 & 519 & 601 \\
40 Footer & 1860 & 1044 & 816 \\
\hline
\end{tabular}

Source: Data gathered by Royal Cargo as of October 2010 as cited in the Joint Foreign Chambers of the Philippines Note: The difference is equal to cost savings from using foreign transhipment routes instead of a single domestic shipping a good from Manila to Cagayan de Oro.

Table 7. Comparative shipping costs in selected domestic and international shipping routes

\begin{tabular}{lrrrr}
\hline Indicators & MNL-DVO & HKG-MNL & BKK-MNL & KLANG-MNL \\
\hline Distance (in nautical miles) & 519 & 619 & 1,189 & 1,343 \\
Sailing time (no. of days) & 1.5 & 1.5 & 8 & 8 \\
Freight/nautical miles (in USD) & 1.2 & 0.4 & 0.5 & 0.5 \\
\hline Source : G. LLanto \& E. Basilio, 2005 \\
Note: MNL - Manila; DVO - Davao; HKG - Hong Kong; BKK - Bangkok; Klang - Port Klang, Malaysia
\end{tabular}

61. As a result, domestic shipping costs are a substantial part of logistic costs in the Philippines. Logistics costs account for 24 to 53 percent of wholesale price in the Philippines compared to less than 20 percent in other countries in the East Asia region. ${ }^{22}$ Shipping and port handling costs account for an average of 35 percent of logistics cost, 8 percent (to as high as 30 percent) of wholesale price depending on the goods and routes, and an average of 5 percent of retail price (Tables 8 and 9). ${ }^{23}$

\footnotetext{
${ }^{22}$ Part of the high cost of logistics in the Philippines is driven by its archipelagic geography. However, Indonesia, another archipelago, has lower unit shipping cost (Table 4). This indicates that geography alone does not fully explain why the Philippines has high logistics cost.

${ }^{23}$ These figures are based on data from Japan Bank for International Cooperation [JBIC] (2002) and University of Asia and the Pacific Industry Monitor (2002) as cited in Japan International Cooperation Agency and Maritime Industry Authority (2005). JBIC (2002) was cited by Hussein S. Lidasan and Jun T. Castro in their PowerPoint presentation titled "Philippine Intermodal Logistics System and Policies," delivered in a logistics conference held in Dusit Hotel, Makati, Metro Manila, on February 5, 2009.
} 
Table 8. Shares to total logistics cost

(\%)

\begin{tabular}{lc}
\hline & Average \\
\hline Shipping & 27.2 \\
Ports (cargo handling) & 6.9 \\
Trucking & 39.5 \\
Storage & 17.9 \\
Handling & 32.8 \\
Others & 30.3 \\
\hline
\end{tabular}

Sources: Arnold and Villareal (2002), JBIC (2002), JICA and MARINA (2005), BAS (2011a), BAS (2011b), and University of the Philippines Mindanao (2013)
Table 9. Average shares to total logistic costs and Philippine prices (\%)

\begin{tabular}{lccc}
\hline & $\begin{array}{c}\text { Logistics } \\
\text { cost }\end{array}$ & $\begin{array}{c}\text { Wholesale } \\
\text { price }\end{array}$ & $\begin{array}{c}\text { Retail } \\
\text { price }\end{array}$ \\
\hline Shipping & 27.2 & 6 & 2.8 \\
Ports & 6.9 & 2.4 & 2.1 \\
Shipping and ports & 34.1 & 8.4 & 4.9 \\
\hline
\end{tabular}

Sources: Arnold and Villareal (2002), JBIC (2002), JICA and MARINA (2005), BAS (2011a), BAS (2011b), and University of the Philippines Mindanao (2013)

62. However, such comparisons should be treated with extreme caution. There are several factors that may generate differences in tariff rates, which should be taken into account:

- International shipping lines benefit from economies of scale as they tend to have larger container vessels carrying at least 80020 -foot equivalent unit (TEU) compared to local cargo vessels with 150 - 200 TEU capacity and significantly less for passenger, break bulk, and container combination vessels;

- Vessels utilized in domestic shipping are geared vessels (i.e., with cranes), ${ }^{24}$ which are more expensive to acquire and operate, given the limited supply of geared vessels. Most ports in the Philippines do not have specialized cargo handling equipment needed to service gearless container vessels. Container vessels on international routes are normally gearless (i.e., without cranes) since the ports they serve have complete cargo handling equipment;

- International liner shipping operates under a different regulatory and market environment and is not subject to the same rules as domestic shipping in the Philippines. Vessels are often registered under so-called "flags of convenience," which bring certain cost advantages;

- The international feeder routes, which feed into mega-container vessels with capacities of 12,500 TEUs at hub ports. Feeder tariffs do not necessarily properly reflect the standalone costs of the feeder ship operation;

- Freight rates are strongly influenced by the direction of trade. If trade is significantly imbalanced, rates in the higher volume direction will be much higher than in the

\footnotetext{
${ }^{24}$ Geared vessels or vessels with onboard cranes are slowly being phased out as major international ports already provide their own gantry cranes to load/unload containers. Refrigerated vessels or reefer vessels are specialized vessels used in the transportation of cargo requiring refrigeration such as pineapples, mangoes, etc. With the widespread use of refrigerated containers by international cargo liners and their increasing allocation of slots on vessels for reefer containers, the need for reefer vessels has also diminished significantly.
} 
reverse direction; and

- Quoted freight rate may or may not include terminal handling charges at either end of the journey. These costs may comprise a significant percentage of total shipping cost (typically one-third, but can be more than 50 percent under some circumstances).

For these reasons, comparison between international and domestic freight rates cannot be regarded as firm evidence that domestic freight rates reflect excessive costs, or that excess profits are being made by domestic shipping operators.

\section{Low quality of service}

63. Domestic shipping is characterized by a low quality of service. In the East Asia region, the Philippines trails behind its neighbors in various logistics performance and connectivity indices. For instance, in liner shipping connectivity, the Philippines ranked $66^{\text {th }}$ out of 157 countries in 2013, and performs the worst among a group of East Asian comparators. It is at the bottom in terms of frequency with which shipments are delivered within expected time and is third to the bottom in terms of arranging competitively-priced shipment (Figure 1 and Table 10). Moreover, the Philippines has shown minimal improvements in the last 10 years.

Figure 1. Deterioration in Philippine shipping connectivity in the last decade...

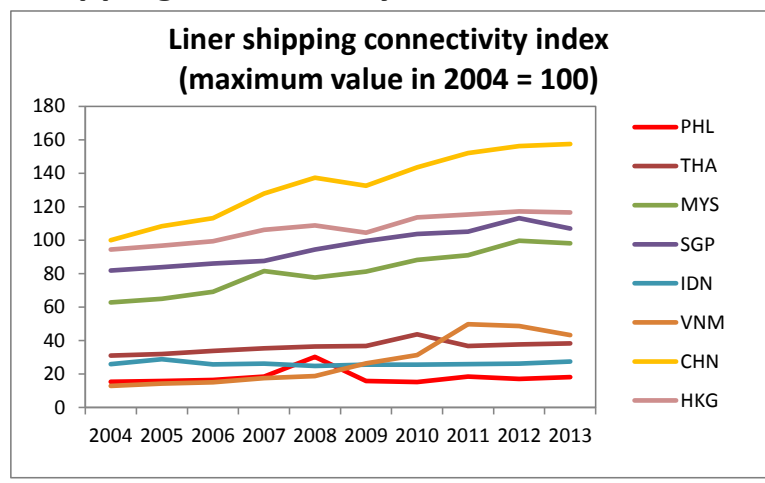

Table 10. ... as well as in other logistics performance indicators.

\begin{tabular}{lccc}
\multicolumn{4}{c}{ Logistics performance index (1=low to 5=high), average for 2007-12 } \\
\hline & $\begin{array}{c}\text { Frequency with which } \\
\text { shipments are delivered } \\
\text { within expected time }\end{array}$ & $\begin{array}{c}\text { Ease of arranging } \\
\text { competitively priced } \\
\text { shipments }\end{array}$ & $\begin{array}{c}\text { Quality of trade } \\
\text { and transport- } \\
\text { related }\end{array}$ \\
\hline Singapore & 4.35 & 3.90 & 4.23 \\
Hong Kong & 4.18 & 3.80 & 4.04 \\
Malaysia & 3.90 & 3.48 & 3.45 \\
China & 3.81 & 3.40 & 3.50 \\
Thailand & 3.81 & 3.25 & 3.20 \\
Indonesia & 3.47 & 2.93 & 2.71 \\
Vietnam & 3.45 & 3.10 & 2.71 \\
Philippines & 3.34 & 3.12 & 2.56 \\
\hline
\end{tabular}

Source: WDI

64. Low quality of service is also pronounced in cargo handling. The lack of high quality shore-based handling equipment is reflected in poor cargo handling productivity and delays in many ports. Interviews with various stakeholders reveal that cargo handling performance, especially in the loading and unloading of break bulk cargo, is poor. This results in significant delays in shipping, increasing shipping costs, and decreasing service reliability (IFC 2013b).

\section{Poor safety record and high frequency of maritime accidents}

65. The industry's low quality of service and poor safety standards are most evident in the high number of maritime accidents. A comparative analysis from the ASEAN-Japan Transport Partnership database shows that in the East Asia Region, the Philippines has the highest casualty rate and this is $\mathbf{4 0}$ percent higher than the second ranked country, Indonesia (Table 
11). ${ }^{25}$ On average, there were 228 ships involved in accidents and 303 casualties per year in the Philippines from 2004 to 2012. Philippine Coast Guard (PCG) data also show a similar trend. From 1995 to 2006, there were 1,982 maritime accidents, or an average of 167 accidents per year. Casualties (both lives lost and missing people) numbered 2,482, or an average of 207 casualties per year (Figure 2). Of the cases documented by the PCG, around 80 percent have the potential to compromise safety of cargo, and more importantly, of the passengers and crew. The most frequent type of maritime accident was capsizing (30 percent), followed by ship grounding (18 percent), and sinking (17 percent) (Figure 3). Box 2 discusses some of the country's major maritime accidents.

Table 11. Casualties and ships involved (2004-2012)

\begin{tabular}{lccc}
\hline Casualties & $\begin{array}{c}\text { Number of ships } \\
\text { involved }\end{array}$ & $\begin{array}{c}\text { Casualties/Total } \\
\text { fleet size }\end{array}$ \\
\hline Singapore & 0 & 2 & 0 \\
Myanmar & 13 & 13 & 0.046 \\
Thailand & 31 & 34 & 0.002 \\
Vietnam & 44 & 95 & 0.003 \\
Indonesia & 215 & 20 & 0.033 \\
Philippines & 303 & 228 & 0.118 \\
Hong Kong & NA & NA & NA \\
China & NA & NA & NA \\
Malaysia & NA & NA & NA \\
\hline
\end{tabular}

Source: ASEAN-Japan Transport Partnership

Notes:

1. Total size of fleet is the sum of domestic cargo fleet, domestic passenger fleet, passenger river fleet, and cargo river fleet

2. There is no record of a domestic shipping fleet for Singapore, as a proxy, international merchant fleet was used

\footnotetext{
${ }^{25}$ The Philippines also has the highest relative casualty rate, surpassing Myanmar. This is measured by the ratio of total casualties to total fleet size.
} 


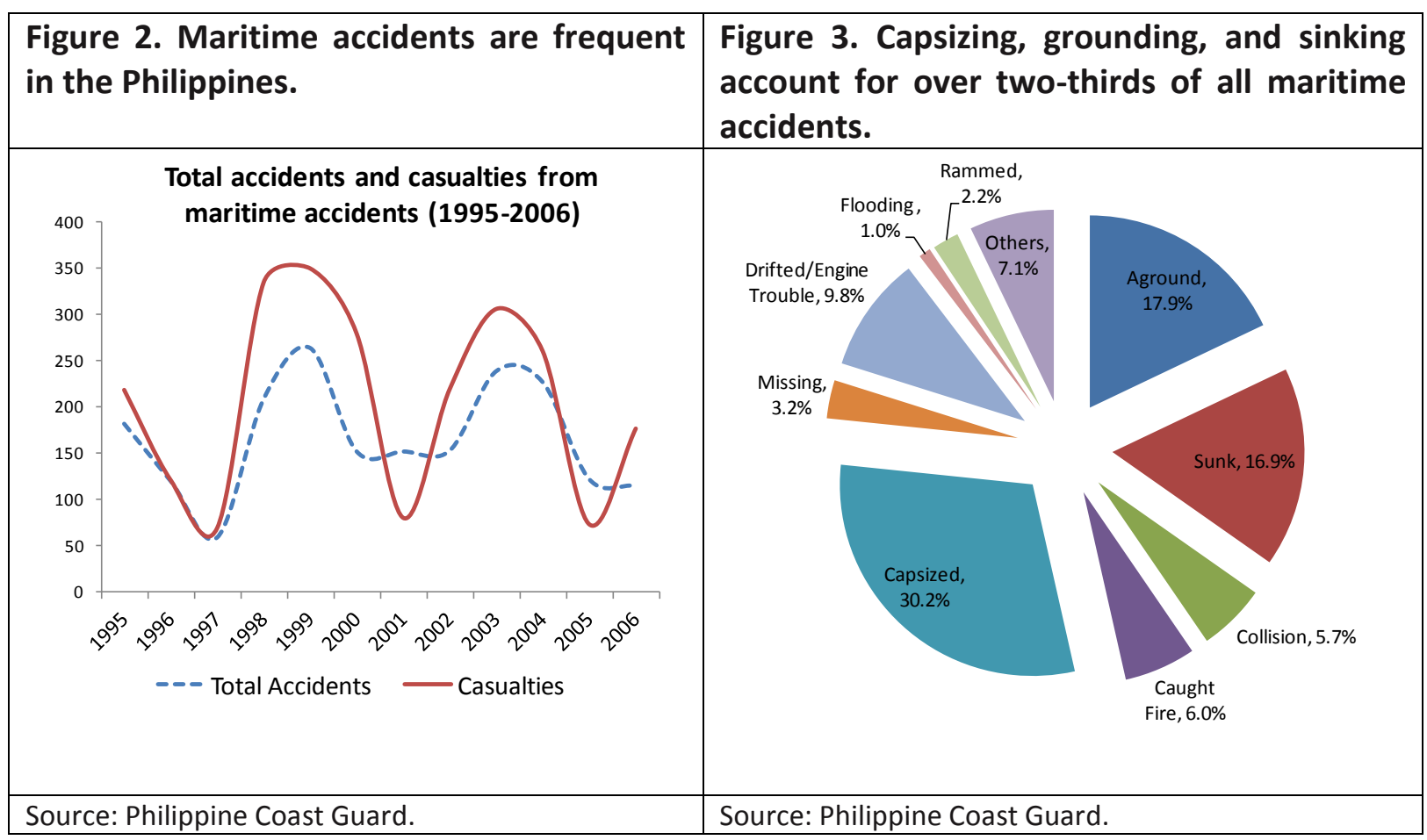

Box 2. Worst maritime accidents in the world

The Philippines is home to some of the worst peace-time maritime accidents in the world. In December 1987, MV Doña Paz, a passenger ferry owned by Sulpicio Lines with a capacity of 1,518 passengers, collided with MT Vector, a small tanker carrying 8,800 barrels of gasoline. The collision sparked a massive fire and resulted in the death of around 4,000 people, a clear indication that MV Doña Paz was severely overloaded. Only 26 survivors were reported. Preliminary investigations showed that the incident was a result of negligence and inability to follow proper safety regulations. ${ }^{26}$ Despite ongoing investigation, Sulpicio Lines was allowed to continue operating. ${ }^{27}$

In June 2008, MV Princess of the Stars, also owned by Sulpicio Lines, sailed during a strong typhoon. Strong winds pushed it against the rocks. The ship capsized and resulted in over 1,000 casualties. Despite poor weather conditions, the ship's captain took the risk of continuing the trip, resulting in the country's worst maritime accident in 20 years. The Board of Maritime Inquiry concluded that human error led to the accident.

In August 2013, MV St. Thomas Aquinas, a passenger ferry owned by $2 \mathrm{GO}$ Shipping Lines, and Sulpicio Express Siete, a cargo ship owned by Philippine Span Asia Carrier (formerly Sulpicio Lines), collided in fair weather just 2 kilometers from the shore of Talisay City in

\footnotetext{
${ }^{26}$ An investigation by the Board of Marine Inquiry claimed that both owners and operators showed gross negligence and complete lack of care. The board found that the Vector Shipping Corporation did not possess a license to operate the vessel and that the crew of MT Vector was not qualified to run the tanker.

${ }^{27}$ In the absence of a final ruling, shipping companies can insist that they be allowed to continue operation.
} 
Cebu Province. Over 116 lives were lost. As in the past, human error was determined to be the cause of the accident. According to preliminary investigations of the Board of Maritime Inquiry, the accident occurred because of a failure of the 2 ships to communicate. Sulpicio Express Siete, the outgoing vessel from Cebu, used the inbound lane leading to the collision with the inbound MV St. Thomas Aquinas. ${ }^{28}$ The captains of both ships claim that they tried to contact each other by radio in order to avoid crossing each other's path but without success. Both the ferry and cargo ship also reportedly failed to comply with labor standards and safety regulations. ${ }^{29}$ One of the safety regulations violated by both ships was the lack of the required safety committee or safety officers to ensure the health and safety of the passengers and crew.

Source: Board of Maritime Inquiry and various news articles, notably http://www.philstar.com/opinion/2013/08/19/1107101/editorial-dangerous-waters, http://www.rappler.com/nation/37161-sulpicio-express-siete-wrong-lane-cebu, http://www.gmanetwork.com/news/story/116375/news/nation/sulpicio-bucks-bmi-findingson-princess-tragedy http://newsinfo.inquirer.net/327123/dona-paz-victims-waiting-for-justice-25-years-after

\footnotetext{
${ }^{28}$ This suggests that apart from human error, standard operating procedures and safety protocols were also violated as the investigation revealed that it was common practice for outbound ships to take the inbound lane to avoid shallow waters.

${ }^{29}$ This finding is based on the Department of Labor and Employment's initial investigation. The extent of non-compliance has not been finalized.
} 


\section{Underlying reasons for the industry's inefficiency}

66. High shipping cost, low quality of service, and poor safety standards are the results of a number of factors. In shipping, the oligopolistic market structure and low profitability leading to lack of investments in new ships are the main reasons for the industry's inefficiencies. Other sources of inefficiencies are the lack of market scale, which is exacerbated by the lack of connectivity, network planning, and consolidation, weak port infrastructure, and conflict of interest in the Philippine Ports Authority.

\section{Oligopolistic market structure}

67. There are many companies offering commercial shipping services in the Philippines, ${ }^{30}$ but scheduled operations (i.e., liners) are dominated by a few firms. ${ }^{31}$ The bulk of sea freight is provided by tramp services. They provide an alternative to scheduled operations, mostly for bulk or break bulk cargo on a contract basis. Their ports of call cover those that are not served by liners. Their rates are not reported to MARINA. While required to have a Certificate of Public Convenience (CPC) as a tramp operator, their operations are seldom monitored and no statistics are available on the volume of cargo carried.

68. Scheduled operations are dominated by a few companies. In 2011, the 3 biggest shipping companies, 2 GO Group, Philippine Span Asia Container (formerly Sulpicio Lines), and Solid Shipping, accounted for some 38 percent of the freight market. ${ }^{32}$ The next 2 largest companies, NMC Container Lines and Asian Shipping, accounted for around 7 percent of the market. Many of these liners are long time players.

69. Most routes are served by 1 or 2 shipping companies. Of around 54 primary routes, over 40 percent are served by a single operator. A third of the routes are served by 2 operators. Less than one quarter of routes are served by 3 or more operators (Figure 4). In general, high volume routes which are financially more attractive, such as Manila-Cebu, Cebu-Cagayan de Oro, and Manila-Davao, attract many players, as many as 5, while de facto monopolies exist

\footnotetext{
${ }^{30}$ Between 1996 and 2008, there was an average of 37 shipping firms in the Securities and Exchange Commission's (SEC) list of top 5,000 corporations. According to MARINA, there were 2,802 shipping operators in 2012, of which, 555 are partnerships/corporations.

${ }^{31}$ The small number of dominant players in scheduled operations is the result of several mergers. For instance, in 2010, Negros Navigation acquired Aboitiz Transport System Corporation (ATSC) and all its subsidiaries to form 2 GO Group. This new company also acquired several other major players such as Supercat Fast Ferry, Philippine Fast Ferry Corporation, and Cebu Ferries Corporation. Philippine Fast Ferry, in turn, is the result of the merger between Universal Aboitiz and Sea Angels Ferry Corporation (a subsidiary of Negros Navigation) in 1998. Cebu Ferries was established in 1996 as a subsidiary of WG\&A. ATSC emerged from Aboitiz Equity Ventures, the holding company of Aboitiz Shipping Corporation, and WGA. The latter was formed in 1995 when William Lines, Gothong Lines, and Aboitiz Shipping Corporation merged. Magsaysay Lines was formed when Lorenzo Shipping Lines and NMC Container Lines merged.

${ }^{32}$ Market share is computed as the share of the top 5 firms' revenues to the total revenues of shipping companies included in the SEC list of top 5,000 firms. Shipping companies are identified with PSIC codes 61102, 61103, and 61104 for ocean freight transport, inter-island water passenger transport, and inter-island water freight transport, respectively. This includes RoRo and tramp.
} 
on routes with low demand (e.g., Bacolod City - General Santos City, Iloilo to Davao, and Cebu City - Zamboanga) (Figure 5).

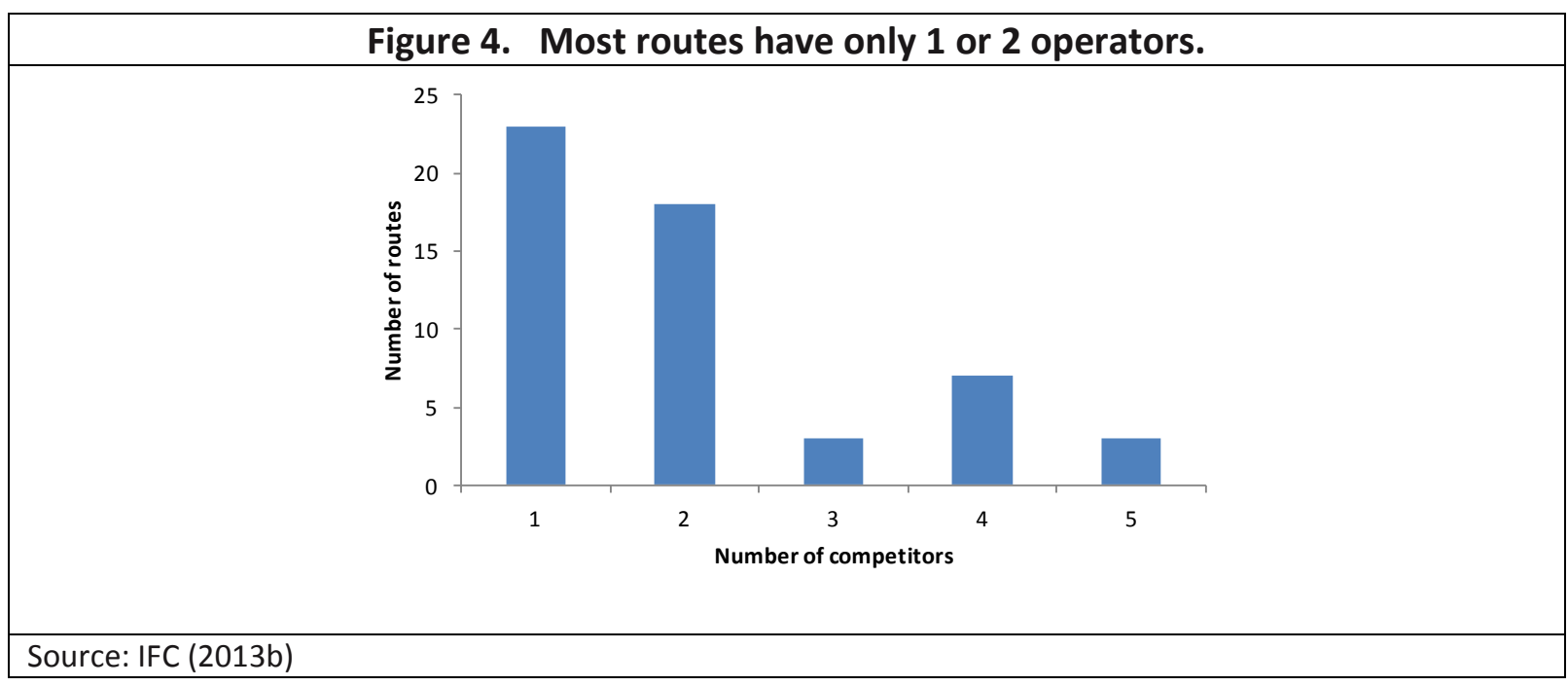

70. Significant market entry barriers exist. Current regulations favor incumbents and make it hard for new firms to enter the industry. Incumbents are allowed by law to object to the granting of a CPC, which authorizes the operation of a ship to new entrants. Cumbersome and costly procedures and the lack of transparency surrounding the CPC process also deter entry of new firms. In response to these inefficiencies, MARINA has begun to simplify procedures in early 2014 by streamlining the steps needed to register a ship.

71. Several other regulations also contribute to the inefficient operation of the industry. Currently, CPCs do not give priority to quality standards and this manifests in frequent maritime accidents. Each new ship and/or new route requires shipping companies to apply for a new CPC, which can be opposed by incumbents. The high cost of shipping is exacerbated by the requirement to dry dock in the Philippines, ${ }^{33}$ which is generally more expensive (e.g., Chinese dry docks are reportedly up to 3.5 times cheaper than Philippine dry docks), and high tax rates associated with leasing vessels.

\footnotetext{
33 Presidential Decree 1221 requires locally flagged ships, even those engaged in international trade, to dry dock in the Philippines, unless they get a permit.
} 
Figure 5. Low volume routes are served by 1 or 2 operators.

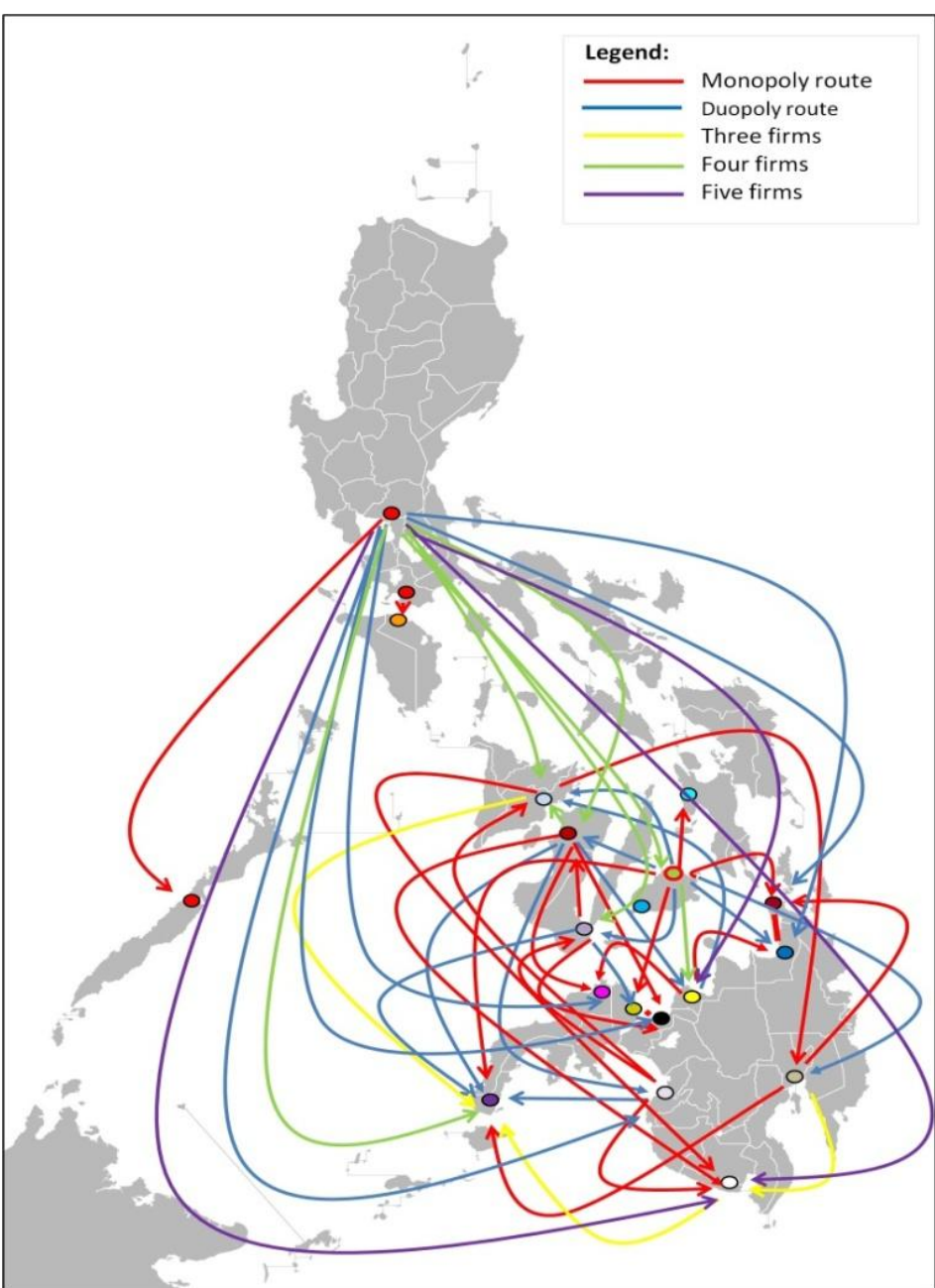

Source: MARINA.

\section{Increased competition yet low profitability}

72. There are indications of increased competition in the domestic shipping industry in the last 15 years following liberalization. The share of revenues of the top 5 shipping companies fell from 69 percent in 1996 to around 45 percent in 2011 (Table 12). The reduction in market share was most evident in the 2 biggest companies, 2 GO Group and Sulpicio Lines, while the 2 smallest players in the top 5 saw their market shares more than double.

73. Yet, profitability in the shipping industry is very low. The often claimed assertion that shipping companies earn monopoly profits is not supported by available data. Financial statements of shipping companies from the Securities and Exchange Commission (SEC) reveal that shipping firms in the SEC Top 5,000 List of Corporations have very low return on assets $(R O A)$, return on equity (ROE), and profit margins (PM). The average ROA, ROE, and PM 
between 1996 and 2008 were 0.6, 1.6, and 0.7 percent, respectively (Table 13). ${ }^{34}$ These ratios were slightly higher at 2.6, 5.3, and 3.2 percent, respectively, between 2005 and 2008 when shipping rates were liberalized compared to the pre-rate liberalization period, suggesting that competitive pressures have contributed somewhat to improved efficiency, though still below international benchmarks. A breakdown of these ratios by firm size reveals that the top 2 firms were less profitable than the other firms.

Table 12. Estimated market shares of top

Philippine shipping companies (1996-2011)

\begin{tabular}{lcccc}
\hline & 1996* & 2001 & 2006 & 2011 \\
\hline 2GO Group & 40 & 32 & 28 & 27 \\
Sulpicio Lines & 21 & 20 & 14 & 6 \\
Solid Shipping & 5 & 6 & 4 & 5 \\
NMC Container Lines* & 1 & 2 & 3 & 4 \\
Asian Shipping & 2 & 1 & 2 & 3 \\
\hline CR5 & 69 & 61 & 50 & 45 \\
\hline
\end{tabular}

*NMC Container Lines started operations in 1997.

\footnotetext{
${ }^{34}$ As a comparison, the average ROA, ROE, and PM of non-shipping firms in the SEC top 5,000 are higher at 3, 10, and 6 percent, respectively for the same period.
} 
Table 13. Profitability indicators

\begin{tabular}{lccc}
\hline & Overall average & Average 1996-2004 & Average 2005-2008 \\
\hline All shipping firms in the SEC Top 5000 & & & \\
Revenue growth & 10.3 & 14.2 & 2.4 \\
Cost growth & 11.2 & 15.7 & 2.2 \\
Profit growth & 8.2 & -5.3 & 35.3 \\
ROA (percent) & 0.6 & -0.7 & 2.6 \\
ROE (percent) & 1.0 & -2.3 & 5.3 \\
Profit-cost ratio & 0.7 & -1.1 & 3.2 \\
\hline & & & \\
Top 5 shipping firms & & & -2.4 \\
Revenue growth & 10.1 & 16.3 & -2.4 \\
Cost growth & 11.5 & 18.5 & -276.0 \\
Profit growth & -75.6 & 24.6 & 1.2 \\
ROA (percent) & 0.4 & -0.5 & 2.3 \\
ROE (percent) & 0.8 & -1.5 & 1.6 \\
Profit-cost ratio & 0.5 & -0.9 & \\
\hline & & & -3.4 \\
Top 2 shipping firms & & & -2.6 \\
Revenue growth & 11.6 & 19.1 & -290.0 \\
Cost growth & 12.4 & 19.9 & -0.8 \\
Profit growth & -194.0 & -146.0 & -1.7 \\
ROA (percent) & 1.0 & 1.4 & -1.0 \\
ROE (percent) & 0.5 & -0.2 & \\
Profit-cost ratio & 2.4 & 3.2 & \\
\hline Soure: Securitis and Exchang & & \\
\hline
\end{tabular}

Source: Securities and Exchange Commission (SEC)

Notes: Domestic shipping rates were deregulated in 2004. After 2008 is not available in usable format.

74. Low profitability reflects competition from unscheduled and opportunistically operating trampers, and from air and land transport. Trampers typically compete on flexibility and price, with some of them operating sub-standard ships. Another major source of competition comes from alternative modes of transportation: the roll-on roll-off (RoRo) services and air transport. Improved arterial roads and strong support for RoRo services since 2003 are making bus transport increasingly popular. Air transport liberalization since 1993 has brought down average air fares by more than 50 percent in real terms, resulting in a five-fold increase in domestic air passengers (see World Bank 2013 for more discussion). Finally, the high incidence of maritime accidents has also drawn passengers away from liners.

75. High input costs also pull down profitability. The overall cost structure of the Philippine domestic shipping industry is broadly similar to that of shipping companies in the East Asia region. Between 2008 and 2012, operating expenditures ${ }^{35}$ of Philippine domestic shipping

\footnotetext{
${ }^{35}$ Operating expenditures exclude general and administrative expenses, finance costs, interest expense, and other nonoperating expenses.
} 
companies averaged around 70 percent of total revenues compared to an average of 80 percent among a group of comparators (Table 13). However, Philippine shipping firms pay more for fuel and repairs compared to firms in other countries. Fuel is the largest cost item at 27 percent of total revenues, and at 41 percent of total operating expenditures (Tables 14 and 15). In contrast, comparator companies, such as Maersk Group, OOCL Hong Kong, and NOL Singapore, registered lower share of fuel cost at around 20 percent of revenues. ${ }^{36}$ Industry insiders explain that Philippine fuel is more expensive since it is not subsidized and a 12 percent VAT is imposed on top of excise tax and import tariff, while fuel in Singapore, Malaysia, and Indonesia are subsidized and are levied lower tax rates.

76. Dry docking, repair, and maintenance are also major expenditure items, accounting for an average of 11 percent of total operating cost (Table 15). Firm level data, however, show that dry docking, repairs, and maintenance can reach as high as 26 percent of revenues. In contrast, the average dry docking cost in the region was 50 percent cheaper and up to 3.5 times cheaper in the case of China (IFC 2013a). The high share of dry docking, repair, and maintenance to total cost reflects government regulations that mandate domestic ships to dry dock in the Philippines. ${ }^{37}$ This has resulted in higher repair and maintenance cost and slower repair time.

\footnotetext{
${ }^{36}$ MISC Berhad of Malaysia (whose cost breakdown was not available) can also be assumed to have access to cheaper fuel as it is a subsidiary of Petronas, Malaysia's national oil company.

${ }^{37}$ The market is typically dominated by a single shipyard for certain types of ships.
} 
Table 14. Operating expenditure and fuel cost as percent of total revenues (2011-12)

\begin{tabular}{lrrrrr}
\hline & ROA & \multicolumn{1}{c}{ ROE } & PM & Fuel cost & Opex \\
\hline Philippine companies (2011-12) & & & & & \\
Sulpicio Lines & 3.1 & 14.3 & 5.1 & 33.2 & 61.3 \\
2GO Group & -1.2 & -4.6 & -1.0 & 28.3 & 69.4 \\
Solid Shipping & 16.0 & 17.9 & 15.5 & 29.3 & 80.0 \\
NMC Container & 3.0 & 9.5 & 2.6 & 14.6 & 87.8 \\
Asian Shipping & 18.0 & 32.3 & 15.3 & 26.6 & 84.9 \\
\hline
\end{tabular}

Industry average $\left(2008^{1}\right)$

Shipping companies in the top 25,000

corporations

3.5

11.7

4.4

n.a.

n.a.

International benchmarks (2012) ${ }^{2}$

Maersk Group

10.1

19.1

12.4

11.7

79.5

MISC Berhad ${ }^{3}$ (Malaysia)

4.3

7.1

16.9

n.a.

77.5

Orient Overseas Limited (HK)

3.8

6.9

4.8

18.8

89.9

Neptune Orient Lines (Singapore)

$-4.4$

$-15.9$

$-3.8$

19.9

94.5

Evergreen Taiwan

0.0

0.1

0.2

23.2

93.0

Yang Ming Marine (Taiwan)

$-0.1 \quad-0.2$

$-0.1$

25.5

98.8

China COSCO

$-4.5$

$-17.7$

14.0

102.5

China Shipping Container Lines

0.3

0.6

31.5

100.7

$1 /$ Latest available SEC data

2/ Companies included here are some of the largest international shipping companies with ship capacity of more than 100,000 TEU

3/ Malaysia International Shipping Corporation

Notes: Operating expenditures (opex) includes cost of services and cost of goods sold and exlcudes general and administrative expenses, finance costs and other non-operating expenses. Return on assets $(\mathrm{ROA})=$ income before tax / total assets, return on equity $(\mathrm{ROE})=$ income before tax / total equity, profit margin $(P M)=$ income before tax / total revenues.

Sources: SEC Top 25,000 Corporations and company annual reports

Table 15. Breakdown of operating expenditure of the top 5 Philippine shipping firms

\begin{tabular}{lcccccc}
\hline \multicolumn{1}{c}{ Percent of total operating cost } & $\mathbf{2 0 0 8}$ & $\mathbf{2 0 0 9}$ & $\mathbf{2 0 1 0}$ & $\mathbf{2 0 1 1}$ & $\mathbf{2 0 1 2}$ & Average \\
\hline Operating expense & & & & & & \\
Fuel, oil and lubricants & 49 & 34 & 38 & 41 & 43 & 41 \\
Depreciation & 8 & 10 & 12 & 9 & 7 & 9 \\
Personnel cost & 6 & 7 & 6 & 7 & 6 & 6 \\
Dry docking, repairs and maintenance (vessel) & 12 & 14 & 13 & 11 & 3 & 11 \\
Stevedore, wharf labor & 4 & 4 & 3 & 4 & 2 & 4 \\
Others & 22 & 30 & 28 & 29 & 38 & 29 \\
\hline
\end{tabular}




\section{Lack of investment in ships}

77. Low profitability has resulted in low rates of investment. The domestic shipping industry lags behind its ASEAN counterparts in new ship acquisition. The average age of the country's domestic passenger, general cargo, and container ships is around 30 years old compared to 8 years old among top Asian shipping companies (Table 16). ${ }^{38}$ Aging ships are one reason for the high incidence of maritime accidents in the Philippines. They also contribute to high cost structure and inefficiencies in operation. The overall result of this vicious cycle is stagnation of the industry, which adversely impacts the economy through high logistics cost, high food prices, and weak job creation.

Table 16. Comparative Asian shipping fleet age

\begin{tabular}{lc}
\hline & Average fleet age (years) \\
\hline Philippine companies (2011-12) & 32.1 \\
Sulpicio Lines & 29.9 \\
2GO Group & 26.2 \\
Solid Shipping & 23.8 \\
NMC Container & 18.9 \\
Asian Shipping & \\
\hline & \\
International benchmarks (2012) & 12.1 \\
MISC Berhad (Malaysia) & 5.0 \\
Orient Overseas Limited (HK) & 6.5 \\
Neptune Orient Lines (Singapore) & 6.5 \\
Yang Ming Marine (Taiwan) & 10.2 \\
China COSCO & \\
\hline
\end{tabular}

Source: SEC, Company annual reports

\section{Lack of market scale}

78. One of the key reasons for high shipping costs is small trade volumes that do not justify big ships that can benefit from economies of scale. ${ }^{39}$ Economies of scale in shipping are derived not from operating cost, as the difference in operating cost between a small vessel and a large vessel is not substantial, but on the carrying capacity of the vessel. In the international picture, the Philippines is a feeder destination, not a hub or main destination.

\footnotetext{
${ }^{38}$ Source: MARINA list of operating vessels as of December 2012 and various ASEAN shipping company websites.

${ }^{39}$ The analysis of lack of scale leading to high shipping cost needs to be tempered by the possibility that these 2 variables are endogenous. Shipping cost can be high due to lack of scale but lack of scale can also be caused by high shipping cost. For instance, businessmen and farmers may decide against expanding their business/planting more because of the high cost of shipping. A reduction in shipping cost can therefore induce an increase in scale.
} 
According to industry insiders, feeder vessels are generally a fourth of the size of mother ships that serve hubs, and feeder ships add around USD 200 in additional unit freight cost. ${ }^{40}$

79. Within the Philippines, domestic cargo trade is also relatively small. In 2011 , domestic cargo throughput in the Philippines amounted to 102 million metric tons or equivalent to 35 percent of Indonesia's 291 million metric tons. ${ }^{41}$ Ironically, compared to Vietnam, a nonarchipelagic country, Philippine throughput is only slightly higher than Vietnam's 80 million metric tons (Table 17).

Table 17. Throughput in selected countries

\begin{tabular}{lrrrr}
\hline & \multicolumn{1}{c}{ Year } & \multicolumn{1}{c}{ Domestic } & International & \multicolumn{1}{c}{ Total } \\
\hline Philippines & 2013 & 101,700 & 147,300 & 249,000 \\
Indonesia & 2011 & 290,542 & 526,964 & 741,629 \\
Malaysia & 2012 & 179,105 & 169,859 & 316,574 \\
Vietnam & 2011 & 79,779 & 140,501 & 199,835 \\
Australia & 2012 & & & $1,034,406$ \\
New Zealand & 2012 & 6,075 & 31,156 & 37,232 \\
\hline Source
\end{tabular}

Source: Various country statistics offices and port authorities

80. Philippine commodity flow data reveal that most of domestic sea trade is concentrated in just a few shipping routes. Routes servicing the Port of Manila, the largest port in the Philippines, account for around 47 percent of total Philippine domestic sea trade. 8 other routes, out of a total of 137 routes, account for another 10 percent of total domestic sea trade.

81. The majority of domestic shipping routes have very small volumes. Table 18 , which shows commodity flows between major ports, reveals that majority of routes account for less than 1 percent of total domestic sea trade. ${ }^{42}$ Small volumes do not warrant a further increase in capacity or size of ships. An analysis of the Register of Ships maintained by MARINA shows that a large number of ships are very small craft, many of them wooden-hulled, that operate very localized service. Some 1,582 vessels or roughly 42 percent of total vessels have sizes that are less than 50 gross register tonnage (GRT). For passenger and passenger/cargo vessels, this proportion is much higher at over 80 percent (1,556 out of a total of 1,943 vessels). This in turn adds to high cost of shipping.

\footnotetext{
${ }^{40}$ See Philippine Inter-Island Shipping Association (2013) for more discussion. According to industry insiders, the size of feeder vessels is typically around 2,000 to 3,000 TEUs (twenty feet equivalent units) while mother ships are typically around 6,000 to 18,000 TEUs.

${ }^{41}$ Indonesia's large domestic trade volume is partly attributed to its much larger economy and the presence of natural resource commodities.

${ }^{42}$ Commodity flow data from the National Statistics Office are given only at the regional level. Commodity flows between ports are not available. To arrive at port level data, the largest port (or 2 largest ports) per region is given the entire region's value.
} 
82. Moreover, many routes have predominantly one-direction traffic. For example, ships plying the Manila to Cebu route are often filled to capacity, but the reverse route is filled way below capacity. In terms of price, the Manila-Cebu leg amounts to around PHP 36,000 per 20foot container from pier to pier but the Cebu-Manila route amounts to only PHP 14,000, reflecting weak demand. Moreover, most domestic shippers do not consolidate cargo, contributing to unfilled capacity.

83. This lack of market scale is ultimately traced to the country's weak agriculture and manufacturing sectors, which are unable to produce more goods at low prices. Moreover, variances in the quality of agricultural produce, such as corn, mean that farmers and agribusinesses prefer to ship in sacks, rather than co-mingle them in bulk, thereby increasing the per unit cost of packaging and shipping.

\begin{tabular}{|c|c|c|c|c|c|c|c|c|c|c|c|c|c|c|c|c|c|}
\hline \multicolumn{18}{|c|}{ Table 18. Eight routes make up almost 60 percent of total domestic sea trade } \\
\hline & & 1 & 2 & 3 & 4 & 5 & 6 & 7 & 8 & 9 & 10 & 11 & 12 & 13 & 14 & 15 & 16 \\
\hline 1 & North Harbor & $0.1 \%$ & & & & & & & & & & & & & & & \\
\hline 2 & Port of San Fernando & $0.0 \%$ & $0.0 \%$ & & & & & & & & & & & & & & \\
\hline 3 & Port of Irene/Port of Aparri & $0.1 \%$ & $0.0 \%$ & $0.0 \%$ & & & & & & & & & & & & & \\
\hline 4 & Port of Limay/ Subic & $5.5 \%$ & $0.4 \%$ & $0.1 \%$ & $0.1 \%$ & & & & & & & & & & & & \\
\hline 5 & Port of Batangas & $0.1 \%$ & $0.0 \%$ & $0.0 \%$ & $0.6 \%$ & $0.0 \%$ & & & & & & & & & & & \\
\hline 6 & Port of Puerto Princesa & $1.3 \%$ & $0.0 \%$ & $0.0 \%$ & $0.2 \%$ & $1.2 \%$ & $0.6 \%$ & & & & & & & & & & \\
\hline 7 & Port of Tabaco/Legazpi & $0.1 \%$ & $0.0 \%$ & $0.0 \%$ & $0.0 \%$ & $0.1 \%$ & $0.2 \%$ & $0.6 \%$ & & & & & & & & & \\
\hline 8 & Port of lloilo & $11.6 \%$ & $0.1 \%$ & $0.0 \%$ & $0.4 \%$ & $0.7 \%$ & $0.3 \%$ & $0.7 \%$ & $3.2 \%$ & & & & & & & & \\
\hline 9 & Port of Cebu & $8.4 \%$ & $0.0 \%$ & $0.0 \%$ & $0.4 \%$ & $0.0 \%$ & $0.1 \%$ & $0.8 \%$ & $1.7 \%$ & $4.6 \%$ & & & & & & & \\
\hline 10 & Ports of Maasin and Liloan & $0.7 \%$ & $0.0 \%$ & $0.0 \%$ & $0.2 \%$ & $0.1 \%$ & $0.0 \%$ & $0.3 \%$ & $0.2 \%$ & $6.1 \%$ & $0.1 \%$ & & & & & & \\
\hline 11 & Port of Zamboanga & $2.2 \%$ & $0.0 \%$ & $0.0 \%$ & $0.3 \%$ & $0.0 \%$ & $0.0 \%$ & $0.0 \%$ & $0.3 \%$ & $1.6 \%$ & $0.0 \%$ & $0.0 \%$ & & & & & \\
\hline 12 & Port of Cagayan de Oro/ligan & $7.0 \%$ & $0.0 \%$ & $0.0 \%$ & $0.4 \%$ & $0.1 \%$ & $0.1 \%$ & $0.4 \%$ & $1.7 \%$ & $5.5 \%$ & $0.8 \%$ & $0.2 \%$ & $1.7 \%$ & & & & \\
\hline 13 & Port of Davao & $5.1 \%$ & $0.0 \%$ & $0.0 \%$ & $0.3 \%$ & $0.0 \%$ & $0.0 \%$ & $0.0 \%$ & $0.1 \%$ & $0.9 \%$ & $0.0 \%$ & $0.2 \%$ & $0.3 \%$ & $0.2 \%$ & & & \\
\hline 14 & Port of General Santos & $2.8 \%$ & $0.0 \%$ & $0.0 \%$ & $0.3 \%$ & $0.0 \%$ & $0.0 \%$ & $0.0 \%$ & $0.2 \%$ & $0.5 \%$ & $0.0 \%$ & $0.2 \%$ & $0.3 \%$ & $0.5 \%$ & $0 \%$ & & \\
\hline 15 & Port of Surigao & $1.2 \%$ & $0.0 \%$ & $0.0 \%$ & $0.2 \%$ & $0.0 \%$ & $0.0 \%$ & $0.0 \%$ & $0.1 \%$ & $1.8 \%$ & $8.1 \%$ & $0.1 \%$ & $0.8 \%$ & $0.0 \%$ & $0 \%$ & $0.4 \%$ & \\
\hline 16 & Ports of Cotabato, Lamitan & $0.1 \%$ & $0.0 \%$ & $0.0 \%$ & $0.2 \%$ & $0.0 \%$ & $0.0 \%$ & $0.0 \%$ & $0.0 \%$ & $0.1 \%$ & $0.2 \%$ & $0.4 \%$ & $0.0 \%$ & $0.0 \%$ & $0 \%$ & $0.0 \%$ & $0.2 \%$ \\
\hline
\end{tabular}

\section{Exacerbated by the lack of connectivity, network planning, and consolidation}

84. The lack of market scale is exacerbated by the lack of connectivity, network planning, and consolidation. In general, national and regional transport planning is weak, resulting in significant infrastructure gaps, such as missing regional arterial roads and farm to market roads to connect farms to ports and ultimately to markets. These infrastructure gaps have in turn contributed to the proliferation of public and private ports that spread the market too thinly and therefore reduce scale. For example, Northern Mindanao from Ozamis to Surigao, with a total coastline of around 497 kilometers, has 7 public ports: Cagayan de Oro (CDO), Mindanao Container Terminal (MCT), Iligan, Nasipit in Butuan, Surigao, Bislig, and Ozamis, alongside 29 private ports. Consolidating commercial traffic in the largest port in Cagayan de Oro (MCT) can help increase scale and reduce cost, while allowing private ports to deal with private cargo. 


\section{Lack of port and road infrastructure}

85. Port infrastructure deficiencies also contribute to the high cost of shipping. According to the Global Competitiveness Report 2013-14, the Philippines ranks $98^{\text {th }}$ out of 148 countries in the quality of overall infrastructure. Road infrastructure is ranked higher at $87^{\text {th }}$ but it still trails its neighbors. In terms of port infrastructure, it ranks $116^{\text {th }}$ and ironically was better only compared to Lao (which is a landlocked country) (Table 19). The consequences of these infrastructure deficiencies are severe congestion, long wait time for ships, delays in shipment, and consequently higher cost of shipping.

Table 19. Port infrastructure scores in the region

\begin{tabular}{|c|c|c|c|c|}
\hline Country & $\begin{array}{l}\text { Overall } \\
\text { ranking }\end{array}$ & $\begin{array}{c}\text { Quality of } \\
\text { infrastructure }\end{array}$ & $\begin{array}{l}\text { Quality of } \\
\text { roads }\end{array}$ & $\begin{array}{l}\text { Quality of port } \\
\text { infrastructure }\end{array}$ \\
\hline Singapore & 2 & 5 & 7 & 2 \\
\hline Hong Kong & 7 & 2 & 5 & 3 \\
\hline Japan & 9 & 14 & 12 & 30 \\
\hline Taiwan, China & 12 & 26 & 14 & 29 \\
\hline Malaysia & 24 & 25 & 23 & 24 \\
\hline Korea, Rep. & 25 & 23 & 15 & 21 \\
\hline Brunei Darussalam & 26 & 39 & 35 & 49 \\
\hline China & 29 & 74 & 54 & 59 \\
\hline Thailand & 37 & 61 & 42 & 56 \\
\hline Indonesia & 38 & 82 & 78 & 89 \\
\hline Philippines & 59 & 98 & 87 & 116 \\
\hline Sri Lanka & 65 & 54 & 49 & 73 \\
\hline Vietnam & 70 & 110 & 102 & 98 \\
\hline Lao PDR & 81 & 65 & 65 & 137 \\
\hline Cambodia & 88 & 86 & 80 & 81 \\
\hline Mongolia & 107 & 133 & 141 & 140 \\
\hline Bangladesh & 110 & 134 & 118 & 104 \\
\hline Timor-Leste & 138 & 131 & 146 & 145 \\
\hline Myanmar & 139 & 146 & 138 & 136 \\
\hline
\end{tabular}

Source: The Global Competitiveness Report 2013-14

86. Majority of the country's major domestic ports are not equipped with modern port facilities to handle today's larger and more advanced vessels. In many of the country's ports, cargo handlers cannot deploy modern cargo handling equipment such as quay cranes and other heavy equipment due to the poor condition of ports and weight limitations. In these ports, vessels must rely on on-board cranes. As a result, the shipping industry is constrained to use geared vessels (i.e., vessels with on-board cranes) to handle port cargo. These vessels are more costly to construct and are increasingly short in supply, and consequently more expensive to buy or charter, leading to higher cost of operations and inefficiencies in both port and shipping operations (IFC 2013b). 
87. Maritime access is limited by shallow berths in most Philippine ports. An important factor determining access of ships to ports is the berth depth of both the origin and destination ports. In the Philippines, 60 percent of berths at major public ports have depths that are less than 8 meters. ${ }^{43}$ This means that mid-sized vessels would have to wait for high tide before they can dock while large vessels cannot be accommodated even if demand increases. The resulting reliance on smaller vessels means that shipping companies cannot take advantage of economies of scale to reduce shipping cost even if the market expands.

88. Apart from port infrastructure, the country's weak state of road infrastructure also contributes to high logistics cost. The World Development Indicator (WDI) database shows that the Philippines has only about 40,000 kilometers of paved roads out of 200,036 kilometers in 2003 (20 percent paved), ${ }^{44}$ compared to an average of 198,184 kilometers of paved road (out of 455,702 kilometers or 43 percent paved) among East Asian countries. More importantly, the country lacks adequate farm-to-market roads, which are important conduits to connect farmers to markets. For instance, farmers in Benguet Province face up to 8 hours when bringing their vegetables to Manila (a distance of about $280 \mathrm{kms}$ or $40 \mathrm{~km} / \mathrm{h}$ ), when a more efficient road network can bring this down to at most 4 hours. Inadequate road infrastructure also results in congestion and limits the efficiency of shipping services. For instance, congestion around the Port of Manila decreases truck turnaround time and the amount of cargo/containers that can be carried in a day, and thus adversely impacts the efficiency of shipping services in the country. Port congestion, in turn, results in road significant congestion. Overall, JICA (2013) estimates the total cost of congestion at around PHP 876 billion (around 8 percent of GDP) or PHP 2.4 billion daily.

\section{Conflict of interest in the Philippine Ports Authority}

89. Finally, conflict of interest in the Philippine Ports Authority (PPA) also contributes to higher cost of shipping. The PPA is both a regulator and an operator of ports. It sets cargo handling rates for all its ports but also receives at least 10 percent of all cargo handling fees. ${ }^{45}$ This not only raises the cost of shipping, it also gives rise to real or perceived conflict of interest. This conflict of interest could be removed by shifting away from its port operations mandate so that it can focus exclusively on its regulatory mandate.

\footnotetext{
${ }^{43}$ See JICA-MARINA (2005) for more discussion.

${ }^{44}$ This is based on latest available data from the World Development Indicators.

${ }^{45}$ This is prescribed by Letter of Instruction 1005-A signed by President Marcos in 1980.
} 


\section{Domestic shipping reform}

\section{Maritime Industry Authority (MARINA)}

90. Created on 1 June 1974 under PD No. $474^{46}$, MARINA started functioning as an agency attached to the Office of the President mandating the agency to integrate the development, promotion and regulation of the country's maritime industry. In 1979, through Executive Order No. 546, MARINA was made an agency reporting to the Ministry of Transportation and Communications (MOTC) for policy and program coordination ${ }^{47}$. The succeeding years saw the development and evolution of MARINA - both in organization and in function - to address the demand for reforms in the maritime industry. In 1985, MARINA assumed the quasi-judicial functions of the Board of Transportation (BOT) in franchising involving water transportation services ${ }^{48}$.

91. The Domestic Shipping Development Act of 2004 (RA 9295) and its implementing rules and regulations further amended the mandate of MARINA, and gave MARINA jurisdiction, powers and duties as given in Box 3.

\section{Box 3: MARINA's powers and duties}

Pursuant to RA 9295, the MARINA's power and duties are the following:

- Register vessels;

- Issue Certificates of Public Convenience, or any extensions or amendments thereto, authorizing the operation of all kinds, classes and types of vessels in domestic shipping: Provided, That no such certificate shall be valid for a period of more than twenty-five (25) years;

- Modify, suspend or revoke at any time, upon notice and hearing, any certificate, license or accreditation it may have issued to any domestic ship operator;

- Establish and prescribe routes, zones or areas of operations of domestic ship operators;

- Require any domestic ship operator to provide shipping services to any coastal area, island or region in the country where such services are necessary for the development of the area, to meet emergency sealift requirements, or when public interest so requires;

- Set safety standards for vessels in accordance with applicable conventions and regulations;

\footnotetext{
${ }^{46}$ Presidential Decree No. 474, Providing for the Reorganization of Maritime Functions in the Philippines, Creating the Maritime Industry Authority, and for Other Purposes, June 1974.

${ }^{47}$ Executive Order No. 546, Creating a Ministry of Public Works and a Ministry of Transportation and Communications, July 231979.

${ }^{48}$ Executive Order No. 1011, Establishing the Land Transportation Commission in the Ministry of Transportation and Communications, and for Other Purposes, March 201985.
} 
- Require all domestic ship operators to comply with operational and safety standards for vessels set by applicable conventions and regulations, maintain its vessels in safe and serviceable condition, meet the standards of safety of life at sea and safe manning requirements, and furnish safe, adequate, efficient, reliable and proper service at all times;

- Inspect all vessels to ensure and enforce compliance with safety standards and other regulations;

- Ensure that all domestic ship operators shall have the financial capacity to provide and sustain safe, reliable, efficient and economic passenger or cargo service, or both;

- Determine the impact which any new service shall have to the locality it will serve;

- Adopt and enforce such rules and regulations which will ensure compliance by every domestic ship operator with required safety standards and other rules and regulations on vessel safety;

- Adopt such rules and regulations which ensure the reasonable stability of passengers and freight rates and, if necessary, to intervene in order to protect public interest;

- Hear and adjudicate any compliant made in writing involving any violation of this law or the rules and regulations of the Authority;

- Impose such fines and penalties on, including the revocation of licenses of, any domestic ship operator who shall fail to maintain its vessels in safe and serviceable condition, or who shall violate or fail to comply with safety regulations;

- Investigate any complaint made in writing against any domestic ship operator, or any shipper, or any group of shippers regarding any matter involving violations of the provisions of this Act;

- Upon notice and hearing, impose such fines, suspend or revoke certificates of public convenience or other license issued, or otherwise penalize any ship operator, shipper or group of shippers found violating the provisions of this Act; and

- Issue such rules and regulations necessary to implement the provisions of this Act: Provided, that such rules and regulations cannot change or in any way amend or be contrary to the intent and purposes of this Act.

\section{Under RA 9295, MARINA's regulatory mandate may be summarized as follows:}

- Develop a strong, modern, safe and competitive domestic merchant fleet owned and controlled by Filipinos or by corporations at least 60 percent of the capital of which is owned by Filipinos;

- Determine the conditions of entry for domestic liner and tramp shipping;

- Formulate and implement operational and safety standards for domestic shipping;

- Assure the financial viability of domestic shipping operators; and

- Determine the impact of new shipping services on the area to be served. 


\section{Domestic market structure}

93. There are a large number of companies offering commercial shipping services in the Philippines, but scheduled cargo shipping operations (liner services) are dominated by a small number of these firms. Concentration has increased recently, as the domestic shipping industry has seen the mergers/consolidation of existing liner shipping companies such as Negros Navigation and Aboitiz Transport Services (now 2GO Group); and Lorenzo Shipping Corporation and NMC Container Lines (Magsaysay Lines).

94. Many of these lines have a long history in domestic shipping operations. A relative newcomer is MCC Transport Philippines Inc (MCC), which commenced operations in 2007. MCC is a joint venture between MCC Transport Pte. Singapore Ltd., Mercantile Ocean Maritime Co. (Filipinas) and ATS Consolidated Inc. This was not part of the Negros Navigation Lines/Aboitiz Transport Services consolidation, as MCC is a separate investment of the Aboitiz group. It operates 2 of the largest domestic container vessels with about 1,012 TEU capacity each, compared to the usual 150 - 250 TEU vessels typically deployed by other domestic liners.

95. MARINA does not keep statistics on the market share of shipping companies. As a result, the estimates presented in Table 20 below are based on information acquired during the interviews, and are indicative only.

Table 20: Indicative Market Shares of Major Liner Shipping Companies

\begin{tabular}{lc}
\hline \multicolumn{1}{c}{ Shipping Company } & $\begin{array}{c}\text { Estimated Share of Domestic } \\
\text { Shipping Freight Market }\end{array}$ \\
\hline 2GO Group (formerly Negros Navigation/Aboitiz Transport System) & $38-40 \%$ \\
Philippine Span Asia Container (formerly Sulpicio Lines) & $12-14 \%$ \\
Solid Shipping Lines & $12-14 \%$ \\
Oceanic Container Lines & $2-4 \%$ \\
MCC Transport Philippines, Inc. & $9-10 \%$ \\
Lorenzo Shipping Lines/ NMC Container Lines (Magsaysay Lines) & $15-17 \%$ \\
Others & $\approx 12 \%$ \\
\hline TOTAL & $100 \%$ \\
\hline
\end{tabular}

Source: Result of Mission interviews (January 13-29, 2012)

96. While most attention has been focused on liner shipping, independent trampers carry a large volume of sea freight. They provide alternative shipping services mostly for bulk/break bulk cargo on a contract basis. Their ports of call include those that may or may not be served by liner shipping and shipping contract charges are not reported to MARINA, remaining a private transaction between the shipper and the tramp operator. While required to have a CPC as a tramp operator, their operations are seldom monitored and no statistics are available on cargo volume carried.

\section{Concentration on individual routes}

97. Market conditions vary by route, ranging from a monopoly operator in 1 route to 5 operators on the most crowded routes. A monopoly may exist on a route where there is less 
demand for freight and passenger capacity such as Bacolod City - General Santos City; Iloilo to Davao; Cebu City - Zamboanga, On the other hand, routes with high cargo volume (such as Manila - Cebu City, Cebu City - Cagayan de Oro City, and Manila - Davao City) attract several operators because of the financial returns that could be generated. MCC, for example, entered the domestic trade in the high volume routes given the large size of its vessels.

98. However, even on most primary routes the number of operators is low. Of the 54 primary routes for which data was obtained in this assessment, over 40 percent were served by a single operator. A further third were served by just 2 operators, and less than one quarter were served by 3 or more competitors. ${ }^{49}$

\section{Complementary passenger operators}

99. While the study is focused on pure cargo shipping, the configuration of a large number of liner vessels is passenger/cargo. This allowed liner shipowners 2 sources of revenues passenger fares and cargo rates. Current market developments are increasingly leading to specialization in the services offered. Except for the long distance routes, passenger services are now being provided by fast ferries and bus/RoRo vessel mix.

100. With cargo service specialization, shipowners avoid the costly reconfiguration of foreign acquired vessels to domestic service requirements. But domestic liner shipping has lost a significant revenue stream, given increased competition from airline transportation services, ${ }^{50}$ putting pressure on increasing freight rates for the passenger/cargo vessels or acquiring/chartering cargo only vessels, i.e., container vessels. For cargo, new charters or acquisitions have been for container vessels with a minimum of 150 TEU capacity, with MCC deploying the largest vessels with more than 1,000 TEU capacities.

\section{The RoRo system}

101. Roll on-roll off vessels provide short haul services between nearby islands. Cargo is carried on board these vessels on trucks that are driven on and off the ship. The development of the country's north-south and east-west road infrastructures and RoRo ports provided an alternative to shipping transport.

\footnotetext{
${ }^{49}$ Vessel frequencies on the routes may be different among the shipping lines operating in a common route. Other vessel operators may serve the route without knowledge of MARINA, either with a MARINA-issued Certificate of Public Convenience (CPC) for another route (colorum operators), with a tramping CPC used as a regular service or without any CPC. For the break bulk transportation, shipping operators may use RoRo or fastcraft vessels and small wooden crafts (batels) serving the marginal routes, carrying mostly agricultural produce such as copra or basic commodities, i.e., cement, fertilizers, canned foods, etc. in small quantities

${ }^{50}$ The market power of liner shipping in domestic passenger service has diminished due to competition from other modes of transportation. The deregulation of domestic air transport has captured a major share of the first- and second-class passengers, given the year-around low fares being offered by Philippines Airlines, Cebu Pacific and other domestic budget carriers, with fares close to the first/second-class rates of shipping lines. The shorter travel time and the comfort provided more than compensate for the minimal price difference, enabling domestic airlines to capture a sizeable chunk of the passenger market from liner shipping.
} 
102. But so far, the impact has largely been on passenger traffic where provincial bus transport offered more efficient terminal to door service for passengers destined to areas along the major bus routes. This has eliminated the inconvenience of land transfers at the port for the final leg of the trip to the destination.

103. The liner shipping industry does not consider RoRo as a competitor to its principal cargo business. Improvement in road infrastructures has caused some short haul shipping services to stop, but this is a natural progression of the supply chain where land transport's comparative advantage in the short routes is enhanced. Cargo trucks cannot offer the capacity of domestic vessels in the number of containers and volume of bulk and break bulk cargo that can be carried. In the end, it is still the shipper who selects the appropriate mode for his cargo given transport costs and travel time.

104. A re-alignment in the supply chain has already occurred and will continue, where niche markets will develop for RoRo/land transport and shipping, with shipping focusing on its cargo services on the long haul routes.

\section{Economic regulation of domestic shipping}

105. Regulation of rates and entry in scheduled transport services was a common practice in many countries up until the 1980s. However, beginning with the deregulation of transport industries in the United States under the Carter administration, regulation of prices and entry in most jurisdictions have been liberalized and, in many instances, completely abolished. ${ }^{51}$

106. Economic regulation of the domestic shipping industry of the Philippines has a long history. The rates that liner shipping operators could charge were first regulated in 1928. Control of entry on shipping routes was introduced in 1972. In line with developments elsewhere, the past three decades have seen a gradual, if intermittent, move towards deregulation.

\section{Deregulation of rates and fares}

107. Fares and freight rates were progressively liberalized through a series of Memorandum Circulars between 1989 and 1994, culminating in the formal deregulation of most freight rates and passenger fares through Executive Order 213 in $1994 .{ }^{52}$ However, in practice:

"[O]perators were not allowed to determine on their own the rates they will charge for their services. Instead, the Domestic Shipping Consultative Councils (DOSCONs), composed of shippers/consumers, operators and representatives from the government, was instituted to provide a forum for consultations and negotiations for the implementation of the deregulated rates or any upward adjustments of the rates. Hence, the deregulation, as provided for in EO 214, only modified the process of fixing cargo rates-a task previously

\footnotetext{
${ }^{51}$ Thomas Gale Moore, "Surface Freight Transport Deregulation", The Concise Encyclopedia of Economics, $2^{\text {nd }}$ Edition.

${ }^{52}$ EO No. 213, Deregulating Domestic Shipping Rates, 28 November 1994.
} 
exercised by the government through a quasi-judicial process." ${ }^{53}$

Revised implementing guidelines that provided more effective rate-setting autonomy for shipping operators were introduced in 1999, through MC No $153^{54}$, which, amongst other things, abolished the DOSCON process.

108. The full deregulation of rates and charges was achieved with the passing into law of RA 9295. Chapter III of this Act, which defines the future role of the MARINA, bears the title "Deregulation of Domestic Shipping Industry - Authority of the Maritime Industry Authority", and Section 8 establishes the right of shipping operators to fix their own freight rates "provided that effective competition is fostered and the public interest is served".

109. These reforms appear to have been effective. The shipping industry has been freed from rate regulation and rate competition is now the norm rather than the exception. There are views that shipping rates are still high because shipowners are colluding in setting shipping rates, but there appears to be no hard evidence of this and market conditions make it unlikely.

110. Shipowners do group themselves into associations such as the Philippine Liner Shipping Association (PLSA) and the Philippine Interisland Shipping Association (PISA), but these organizations objectives are to represent the interests of the sector. It is not their function to set shipping rates. Given the deregulation of shipping rates, there is no incentive for the industry to set a uniform shipping rate as these could not be effectively enforced and the market power of the big shippers (such as Nestle, Procter and Gamble, Unilever) enable them to tender their business to the lowest bidder by making the shipping companies bid against each other (Box 4).

\section{Box 4: Rate discounting in shipping}

Rate discounting, particularly on freight rates, is a common practice in the industry. Even when there are government regulations on rate setting, the official rates become just a benchmark or a base from which to discount. Actual freight rates are usually the product of bargaining between shippers and shipping operators (Dick 1987).

Discounting drives up price competition in the industry. To lessen the pressure for rate discounts, shipping companies with established financial position offer longer-term payments. On the other hand, forwarders, traders, and large companies that distribute their own products can make bargains for large discounts by offering a contract for their cargoes for a fixed period. Guaranteed by the security of a contract and a large volume of cargoes, a shipping company can thus settle for a low margin for its shipping rates.

\footnotetext{
${ }^{53}$ Austria, op.cit., p37/

54 Memorandum Circular No 153, Revised Rules and Regulations Implementing Deregulation of Domestic Shipping Rates, 16 December 1999.
} 
Any discount can be readily matched by competitors. Thus, in the face of intense rate competition, the best strategy for a shipping company is to become the market leader in terms of quality of service. In practice, freight rates are not the primary but the balancing item in the services negotiated with shippers, as shippers and traders are more concerned with the safety of their cargoes.

Source: Myrna S. Austria, "Liberalization and Deregulation in the Domestic Shipping Industry: Effects on Competition and Market Structure," Philippine Journal of Development, First Semester 2003.

\section{Liberalization of entry}

111. Control of entry on shipping routes had the avowed objective of ensuring stability in the provision of services by maintaining a balance between capacity and demand. The rationale is outlined in Box.

\section{Box 5: Rationale for entry regulation in liner shipping}

The common argument for the need to regulate liner shipping is based on the supposed danger of chronic instability due to inherent tendencies to ruinous competition and monopoly (Renardet Sauti Consulting Engineers 1986). That is, the industry is highly vulnerable to price and capacity fluctuations, which lead to ruinous competition and eventually to monopoly, after the weak firms are driven out.

Vulnerability to price and capacity fluctuations, if there are no limits to competition is argued to be associated with the cost structure of the industry. Once a vessel is at berth, the only cost associated with carrying an extra ton of cargo is the cost of loading and discharging it; and such marginal cost is very low, an average of 25 to 30 percent of the freight rate. At such rate, an operator cannot survive. Hence, an operator will find it profitable to take an extra cargo at a rate higher than the handling cost. However, if there is free competition, the rate would be forced to go down to the level of the handling cost whenever there is any surplus in capacity. The industry will then become unprofitable for all operators.

However, the above argument does not seem plausible, as shipping operators do not cut their rates to the level of marginal costs once the ship is at berth. Instead, what influences the behavior of operators is not the marginal cost of an extra ton of cargo, but the cost of an extra voyage or set of voyages and their relation to revenues at pre-determined rates.

Source: Myrna S. Austria, "Liberalization and Deregulation in the Domestic Shipping Industry: Effects on Competition and Market Structure," Philippine Journal of Development, First Semester 2003 
112. In the domestic shipping industry, control of entry was implemented through "grandfather rules" in the granting of license to operate:

"In general, these rules imply that if the demand warrants additional fleet in a route, priority is given to the existing operator to put in the additional vessel to meet the demand; but if there are several existing operators in the route, priority is given to the first applicant. If there is no existing operator in a route, entry is allowed and the new entrant is protected in his investment by not allowing another operator until he has recovered his investment. Under the 3 rules, however, the past service records of the operator/s or the new applicant/s were not taken into consideration" $" 55$.

113. There is now a fairly widespread economic consensus that fears of chronic instability and "ruinous competition" were exaggerated, if not totally unwarranted. Moreover, a series of studies in domestic shipping in the Philippines, undertaken during the 1980s and early 1990s, concluded that the regulatory system was not serving the interests of the community, leading to progressive liberalization of the system.

114. Significant liberalization of entry in shipping was achieved in 1994 with Executive Order $185 .^{56}$ This was intended to:

- Increase production and productivity in the various islands and regions of the archipelago through the provision of effective sea linkage;

- Provide for the economical, safe, adequate and efficient shipment of raw materials, products, commodities and people;

- Enhance the competitive position of Philippine flag vessel in the carriage of foreign trade; and

- Generate new and more job opportunities.

MARINA was instructed to:

- Liberalize the entry of new operators into the domestic water transport industry to enhance the level of competition and bring about reasonable rates and improved quality of services. Competition, provided it was not ruinous, was to be the norm to open up the industry to new investments and to stimulate further economic activity. Specifically, all routes were to be open to at least 2 operators, and any routes that "had been serviced by any operator for an aggregate period of at least 5 years shall be open for entry to additional operators without limit".

- Encourage the entry of operators in developmental routes. An operator who pioneers in the provision of a certain technological level/type of shipping service in a developmental route shall be authorized to charge market-accepted freight and passage rates differing from the authorized tariff.

\footnotetext{
${ }^{55}$ Myrna S. Austria, "Liberalization and Deregulation in the Domestic Shipping Industry: Effects on Competition and Market Structure," Philippine Journal of Development, First Semester 2003, p34.

${ }^{56}$ EO No. 185, Opening the Domestic Water Transport Industry to New Operators and Investors, 28 June 1994.
} 
- Grant a Certificate of Public Convenience to an existing or new operator who acquires a vessel through importation, bareboat charter with option to purchase, lease-purchase, or local construction and allowed to operate such vessel in any route, even if already being served by existing franchised operators for less than 5 years, including developmental routes.

- Allow any change or amendment to the authorized routing pattern of a vessel by an existing authorized operator through: (i) omission or deletion of port(s); (ii) addition of other port(s); (iii) omission and subsequent addition of port(s); (iv) changing the sequence of port calls; and (v) retention of authorized routing pattern but with addition of one or more ports.

115. Deregulation was given a further impetus by the passage of RA 9295. Consistent with the deregulatory direction of this Act, and with its emphasis on the goal of promoting "effective competition", as well as encouraging investment, in domestic shipping markets, significant further steps have been taken towards easing constraints for entry into the liner shipping business. However, MARINA retains the power and authority to issue Certificates of Public Convenience to qualified domestic ship operators, and continues to exercise its discretion on whether to grant a Certificate of Public Convenience to an aspiring entrant.

116. RA 9295 also reaffirms the reservation of the Philippines coastal trade for Philippine operators (cabotage). Franchises, CPCs or any other form of authorization for the carriage of cargo or passenger, or both, in the domestic trade can be granted only to domestic shipowners or operators. Foreign vessels are not allowed to transport passengers or cargo between ports or places within the Philippine territorial waters except upon the grant of a Special Permit by the MARINA when no suitable domestic vessel is available to provide a shipping service that is warranted by the public interest. These Special Permits are generally awarded to vessels with specialized capabilities, like those equipped for oil exploration, infrastructure development, or scientific study, that are not present in the domestic fleet.

\section{The importance of further liberalization}

117. The concentration of domestic shipping operations in the country is not surprising, as it is a feature common to domestic shipping routes in most countries. There are 2 main characteristics of the industry that lead to this outcome:

- There are significant economies of scale in ship operations: many cost items - such as construction costs, crewing, insurance and repair and maintenance costs - increase less than proportionately with vessel size.

- Frequency is an important aspect of the quality of service that a shipping company offers to its major customers. All other things being equal, a service that offers 2 sailings a week is likely to be more attractive to a potential customer - particularly a large shipper of perishable products - than a service offering only a single sailing.

A high degree of concentration on individual routes is therefore a natural consequence of market characteristics, and is unlikely to change. 
118. Given relatively concentrated markets, the threat of potential entry is often the major force disciplining market behavior. Fortunately, natural barriers to entry in the shipping sector are relatively low. Although significant capital investment is required, the overwhelming majority of this investment is in the ships themselves. These assets are extremely mobile, and can be readily redeployed to another market if entry is unsuccessful. Also, for the most part the technology used in the shipping industry is generic and readily available for potential new entrants.

119. For these reasons, in the absence of regulatory or legislative barriers the threat of entry is likely to be real and constant. It is also likely to be effective in disciplining market behavior. This is because the stakes for the incumbent operator are very high. One consequence of concentration is that successful new entry may not mean that an incumbent simply loses market share; it may mean it is forced to abandon the market altogether, if the incumbent does not adjust their services. This process is an essential part of the dynamics of the market. It is the principal means by which competition ensures that shipping lines operate efficiently and do not make excess profits. In seeking to enhance competition in the delivery of domestic shipping services, this assessment has therefore focused particularly on measures that would increase the opportunities and incentives for new players to enter the market, and for existing operators to expand or vary the services they offer.

\section{The need for clarity}

120. The stakeholder consultation process undertaken as part of this assessment revealed that the regulatory system is inconsistently understood. Amongst industry participants, there were, for example, differences of views on the criteria that applied to the issuance of a Certificate of Public Convenience (CPC), and what this implied for the ease (or otherwise) with which one could be obtained. There was uncertainty as to whether an operator who had received a CPC as a tramper vessel (that is, without specifying the intended route for the vessel) could then use that vessel to operate a scheduled service as a common carrier. There were different understandings of the conditions under which foreign registered vessels on charter to Filipino shipping companies could be used to provide domestic shipping services.

121. These uncertainties can in themselves constitute a barrier to entry. Potential new entrants face a lower business risk when the rules that apply in the target market, and the way in which they are applied, are clearly understood by all parties. Uncertainties tend to bias the market in favor of incumbents: where the rules are unclear, those who have been operating in the market for some time can draw on their experience of how things operate, while newcomers do not have this advantage. Improving clarity and certainty will therefore have a pro-competitive effect.

122. Improved communication can help, but the most powerful tool for improving understanding is simplification. Over time, most regulatory systems accrue rules, practices and procedures that may once have been necessary but which are no longer required or appropriate to current conditions. These historical accretions make the system more complex and less transparent than it need be. This appears to have happened in the case of the regulation of domestic shipping in the Philippines. Enhancing the competitive environment 
therefore requires a review of all regulations and practices that could - actually or potentially - restrict the flexibility of shipping lines to provide services wherever, whenever and (subject to safety and environmental constraints) with whatever ships they see a commercial opportunity to do so.

\section{Certificate of Public Convenience (CPC)}

\section{The "prior operator rule"}

123. The prior operator rule is a legacy of the period in which domestic shipping was tightly regulated, and the policy priority was ensuring the stability of services provided by existing operators. Existing operators were given the right to contest the entry of new firms in order to ensure the continuity of service in light of the potential for ruinous competition.

\section{In practice, the application of the rule has been progressively weakened over time (see}

Box). In particular, where the applicant previously had to prove inadequacy of service, more recently the burden has shifted to the existing operator to prove that existing capacity is sufficient.

\section{Box 6: Prior operator rule in shipping}

If the demand warrants additional fleet in a route, priority is given to the existing operator to put in the additional vessel to meet the demand; but if there are several existing operators in the route, priority is given to the first applicant. If there is no existing operator in a route, entry is allowed and the new entrant is protected in his investment by not allowing another operator until he has recovered his investment. Under the three rules, however, the past service records of the operator/s or the new applicant/s were not taken into consideration.

Route liberalization was first introduced in 1992. 2 general principles are observed for the issuance of a license. First, the interest of the public shall prevail over the "grandfather rules." Second, the presumption of public need for a service is deemed in favor of the applicant for a license while the burden of proving that the proposed service is not needed shall be with oppositor/s who is/are the current authorized operator/s.

Given these principles, routes were opened to entry to at least 2 operators (MARINA MC No. 71 and MC No. 80 in 1992). Monopolized routes were opened for entry to additional operators. Operators in developmental routes, on the other hand, were accorded protection for their investment for a maximum period of five years, after which, the route is open to entry to at least one additional operator. This change in rule would definitely encourage the operator to increase his efficiency to recover his investments before competition from additional operators sets in. Entry of newly acquired vessels in routes already served by existing franchised operators, including developmental routes, is also deregulated provided that it will introduce innovative, technologically and cost-effective 
shipping services, among others.

Increase in capacity is also allowed through replacement with a bigger vessel, introduction of additional vessels, and/or increase in frequency of existing vessels. An operator can also change his routing pattern through the omission of ports, addition of one or more ports, or the introduction of an entirely new route provided, however, that the change is not in conflict with the schedule and frequency of existing operators and that no route is left unserved by the rerouting.

The initial liberalization efforts were further strengthened with the issuance of EO No. 185 in 1994 and its corresponding implementing rules and regulations under MARINA MC No. 106 in 1995. In particular, all routes that have been serviced by any operator for an aggregate period of at least five years shall be open for entry to additional operators... In addition, when a vessel is replaced to increase capacity, its license is revoked to ensure that it will not be used anywhere else and, hence, will not result in increased tonnage in the routes. Similarly, when capacity is increased through the introduction of additional vessel that is chartered from a franchised operator, the original franchise of the vessel is revoked.

The implementing guidelines of EO No. 185 were revised under MARINA MC No. 161 in 2000, providing further dimension to the liberalization efforts. In particular, the conditions or criteria under which possible protection could be accorded to operators were specified. These include conditions for the existence of ruinous competition and protection of investment of pioneering operators. Only under the conditions specified should entry of additional operators to a route be restricted. The conditions set therefore added greater transparency to the rules of the game.

Source: Myrna S. Austria, "Liberalization and Deregulation in the Domestic Shipping Industry: Effects on Competition and Market Structure," Philippine Journal of Development, First Semester 2003.

125. Despite this progressive liberalization, the way in which the CPC process is currently administered provides the existing operator with the opportunity to prove adequacy of the existing service or, if it is inadequate, to provide the required capacity (prior operator or grandfather rule). As discussed above, RA 9295 is expressly deregulatory in intent ${ }^{57}$, and formally established the ability of domestic shipping operators to establish their own rates. It preserved the requirement that operators obtain a CPC, and that, in their application for a CPC, operators specify the service that they intend to provide. But it does not expressly require the MARINA to assess or form a judgment on the effect of granting the application on the viability of pre-existing services. Rather, insofar as it refers to the impact of the proposed service on third parties, the clear focus is on "the economic and beneficial effect which the proposed services shall have to the port province or region which it proposes to serve" (See Box).

\footnotetext{
${ }^{57}$ The Title of Chapter 3 of RA No. 9295 commences with the words 'Deregulation of the domestic shipping industry'.
} 


\section{Box 7: Issuance of authority to operate}

The MARINA shall have the power and authority to issue a Certificate of Public Convenience to qualified domestic ship operators, taking into consideration the economic and beneficial effect which the proposed service shall have to the port, province of region which it proposes to serve, and the financial capacity of the domestic ship operator to provide and sustain safe reliable, adequate, efficient and economic service in accordance with the standards set by the government regulation.

Every domestic ship operator shall state in its application the route it proposes to serve, and the service it proposes to offer. Domestic ship operators who do not intend to operate in a fixed route shall nevertheless state in its application the service it proposes to offer.

Source: RA 9295 (2004), Section 7.

126. Since RA 9295 has come into force, MARINA has continued its procedures for evaluating and hearing CPC applications and still requires the applicant to inform the affected liner shipping operators of their application. The adequacy of existing services is assessed through a quasi-judicial process where all parties present their arguments ${ }^{58}$. MARINA staff conducts due diligence on the application including technical evaluation of the applicant's financial capacity, documentary evidences presented, and feasibility study of the route applied for. MARINA also requires the operator-applicant to publish in a newspaper of general circulation information on the application and the date and time of the hearing. It is required to submit a list of the existing operators in the route so that these may be informed of the application and invited on the hearing date for the presentation of arguments.

127. The "prior operator" needs only contest the feasibility study of the applicant and prove that the existing number of vessels is already sufficient and that the route would no longer be financially viable with the entry of an additional operator. The possibility to contest an application delays the entry of a new shipping operator, and constitutes a barrier to entry. It protects the existing operator or operators from competition, making it difficult and risky for new applicants to enter the route.

128. There is a range of views on whether this provision has, in practice, a substantial effect on the ease with which operators can introduce new services. But it clearly creates the possibility that an incumbent will use the process to delay the entry of a new competitor (as indicated by a small shipping operator); to add to the cost that the competitor faces in entering the market; and, in the extreme case, to block entry altogether.

\footnotetext{
${ }^{58}$ Details of the relevant requirements and procedures are set out in MARINA Memorandum Circular No 74-A 13 July 1995.
} 
129. The abolition of the "prior operator rule" is not explicit in RA 9295, but it would be consistent with the general deregulatory intent of the Act. Given the criteria specified in Section 7 of the Act (see Box), it appears open to MARINA to decide on the merits of the application for a CPC without reference to commercial impact of new entry on existing operators, and without according incumbents to right to object to new entry.

\section{Cost of application}

130. Authority to operate in any shipping route for liner and tramp shipping anywhere within the Philippines is granted by MARINA through the CPC or "franchise". The CPC is issued to a domestic shipping corporation and has a validity for a period of not more than 25 years. An initial application fee of USD 0.26 (Php 11.00) per gross ton (GT) is charged, but this does not include document certification fees, vessel registration fees, publication cost, applicant's legal costs and other expenses associated with the processing of the application. The CPCS are issued to citizens of the Philippines, or a partnership/corporation that involved at least 60 percent of the authorized capital stock owned by citizens of the Philippines.

\section{There are three basic considerations for the grant of a CPC to an applicant shipping operator:}

- Proof of Filipino Citizenship. This is consistent with previous legislation including Chapter III, Sections 5 and 6 of RA 9295 which limits such trade to majority-owned Filipino enterprises (60 percent-40 percent). This is also consistent with Article XII Section 11 of the 1987 Philippine Constitution which states that "No franchise, certificate, or any other form of authorization for the operation of a public utility shall be granted except to citizens of the Philippines or to corporations or associations organized under the laws of the Philippines, at least 60 per centum of whose capital is owned by such citizens".

- Financial Capacity. Applicant is required to show proof that he has the financial resources to undertake the service applied for in a safe manner.

- Need for the Service. Applicant is required to show proof that there is need for the service (if none is being provided) or additional capacity (if there are existing operators in the route).

- In addition to the 3 considerations mentioned, the applicant is required, in the preapproval stage, to submit various documents including vessel documents and PPA certification of berthing availability when there is no certainty that the application will be approved. ${ }^{59}$ The applicant typically incurs substantial expense even before MARINA starts the quasi-judicial process on the application.

\footnotetext{
${ }^{59}$ MARINA MC No. 169 enumerated the requirements for submitting an application for a CPC as follows: (i) duly notarized application; (ii) vessel documents including certification of inspection and radio/ship station license; (iii) provisional/final class certificate; (iv) passenger insurance coverage at P100,000.00/passenger; (v) oil pollution cover; (vi) PPA certification of berthing space availability; (vii) financial evaluation documents; (viii) NAMRIA certificate of distance (of the route); (ix) 3 colored photographs of the vessel; and ( $x$ ) feasibility study (for routes with 2 or more operators). In addition, certification as to publication of notice of hearing is also required prior to the hearing of the application.
} 


\section{Differentiation between tramp and liner services}

132. At present, CPCs are divided into "liner CPCs" and "tramper CPCs". In principle, liner CPCs are issued for the operation of scheduled services on fixed routes that offer space to a number of shippers on each sailing, while tramper CPCs are issued to vessels that provide ondemand services, typically to meet the requirements of a single shipper.

133. However, there does not appear to be any effective mechanism for preventing the holder of a tramper CPC from operating a regular scheduled service that provides cargo space to a variety of customers; that is, from operating a liner service. From an economic perspective, this may be beneficial. Operators of tramp ships are an important source of potential new entry on liner routes, and allowing them to freely do so enhances the competitive environment. There seems little to be gained from continuing to formally distinguish between the 2 forms of CPC and the interests of clarity and certainty would be served by eliminating this distinction.

\section{Flexibility within a CPC}

134. In applying for a CPC, the shipping operator is required to specify the ships that it will use and the services that it will provide. Where the service is a liner service, this implies defining the route(s) on which the vessels will be deployed.

135. This practice places limits on the flexibility that an operator has in responding to market conditions by deploying vessels in other routes or replacing an existing vessel with another. As the CPC is issued to the operator, it is able to vary which of the vessels is assigned to which of the routes included on its CPC. But if the operator wishes to redeploy a vessel to a route not specified in the CPC, or to introduce a new vessel, it is necessary to obtain approval to amend the CPC, or to acquire a Special Permit. ${ }^{60}$

136. In a market-based system, vessel deployment should be a management prerogative. Seeking approval imposes additional costs on the shipping operator, as, for each amendment to the CPC, MARINA imposes additional fees. This could be avoided, while retaining the CPC framework, by allowing an operator, once it has been granted a CPC, to vary the routes and vessels covered by the CPC simply by providing notice to MARINA that it intends to make these changes, rather than seeking approval to make them.

\section{Enforcement of quality standards}

137. Despite ongoing improvements in safety administration ${ }^{61}$, the safety and

\footnotetext{
${ }^{60}$ Memorandum Circular No 2006-06, Revised Guidelines in the Issuance of Special Permit (SP) to Operate Ships in the Domestic Trade due to Meritorious Circumstances, 6 October 2006. This Special Permit (valid for 30 to 90 days only) is for the use of a Philippine registered ship on a route prior to obtaining a new CPC, or during peak times, holidays seasons, ships are drydocking, etc.

${ }^{61}$ See Gloria J Victoria Banas, National Measures taken to Address Substandard Shipping, presentation to OECD Workshop on Maritime Transport, Paris, 4-5 November 2004.
} 
environmental performance of domestic shipping operations remains a matter of public concern ${ }^{62}$. Serious maritime casualties are comparatively high for Philippine flagged vessels: a comparative analysis by Lloyd's List Intelligence shows that the Philippines has the $15^{\text {th }}$ highest casualty rate (measured as the number of serious maritime casualties divided by the size of the national fleet) ${ }^{63}$. Inspection of relevant incidents recorded in the International Maritime Organization (IMO) database indicates that the majority of these causalities relate to domestic shipping operations.

138. As well as its obvious importance from a social perspective, the enforcement of appropriate safety and environmental standards is also a competition issue. Effective competition in domestic shipping does require that all participants are held to the same safety and environmental standards. The definition and enforcement of quality standards is a crucial part of the role of MARINA. ${ }^{64}$ The Philippines has subscribed and committed adhering to almost all relevant international conventions in terms of International Maritime Organization, International Labour Organization, International Association of Marine Aids to Navigation and Lighthouse Authorities, and other global standards. By actually enforcing compliances related to manning, safety, shipbuilding, stability, bending and torsion, navigation, the maneuvering gap amongst vessel operators would shrink since obeying to standards has a cost.

139. The process of issuing Certificates of Public Convenience can be a useful regulatory tool in ensuring that this condition is met. The intention that it should do so is clear in RA 9295, which requires that MARINA, in granting an application for a CPC, take into consideration, "the financial capacity of the domestic ship operator to provide and sustain safe, reliable, adequate, efficient and economic service". ${ }^{65}$

\section{Chartering foreign vessels for deployment in the domestic routes}

140. Ships undertaking commercial domestic shipping operations are, as a general rule, required to be locally constructed or purchased and imported into the Philippines. However, the Philippines provides 2 mechanisms for the chartering of foreign owned vessels via a Special Permit and through a bareboat charter.

141. MC 2011-04 provides for the chartering of foreign-owned vessel by accredited companies for operation on domestic routes under particular circumstances ${ }^{66}$. This memorandum circular predicates the issuance of the Special Permit on the "objective of insuring the provision of required shipping services where such is not readily available and

\footnotetext{
${ }^{62}$ See, for example, Dennis Atienza Maliwanag, Philippine maritime safety laws archaic, need reforms, InquirerGlobal Nation, 21 December 2010.

${ }^{63}$ Wally Mandryk, Lloyds List Intelligence, Marine Casualty Profiles, presentation to International Maritime Statistics Forum, Hong Kong, 31 May 2011.

${ }^{64}$ RA No 9295, Section 9.

${ }^{65}$ RA No. 9295, Section 7.

${ }^{66}$ MARINA MC No. 2011-04, Revised Rules on the Temporary Utilization of Foreign Registered Ships within the National Territory, 15 December.
} 
suitable from the domestic fleet" to ensure efficient trade and commerce, delivery of critical service/commodities and infrastructure and development projects. This Special Permit is awarded primarily to specialized ships, such as oil explorers, cable laying vessels and research vessels, that have no counterpart in the country.

142. PD 760 allows for a second mode for chartering vessels through a bareboat charter. This process allows domestic firms to lease a ship for a specific time period to test the feasibility of plying new routes or using new vessel types, without needing to shoulder the full costs of purchasing and importing the vessel outright.

143. While the chartering process has been in existence at MARINA for decades, recent attempts by domestic companies to employ bareboat charters have been made more expensive by the tax policies as interpreted by the Department of Finance and the Bureau of Internal Revenue. Since the passage of PD 760 on the bareboat chartering law in 1975, it had been standard practice in the Philippines to allow the tariff and duty-free entry of bareboat chartered foreign vessels. Instead, bareboat charterers paid a withholding tax at a 4.5 percent rate on the value of the charter party (under PD 1540 and the Tax Reform Act of 1987 - RA 8424) and a re-export bond to ensure that the vessel leaves the country upon the expiration of the charter agreement.

144. However, there is a lack of a clear regulatory basis on said tax status of bareboat chartered vessels, for which the DOF has decided to treat them as direct vessel importations. Current interpretation of the regulations now requires that companies pay the full 3 percent import duties and a VAT of 12 percent on the total value of the vessel. The interpretation of the DOF vis-a-vis the customs and taxes payable on such a transaction remains in conflict with the policies currently understood by MARINA, as well as the shipping industry.

145. The change in the tax status of bareboat chartering has limited the willingness of firms to charter vessels. In certain instances, it has become unfeasible to recover the additional taxes over the course of the limited charter period.

146. The ability to access the international charter market provides an important element of flexibility to domestic shipping operators. This is especially so when innovative technologies are being trialed or new services being tested, but more generally it allows operators to take advantage of opportunities to secure tonnage at the lowest possible cost in a highly competitive global market. With a substantial number of foreign-owned vessels available for charter, due to the decline in international trade and the entry of new vessels displacing older and lower capacity ones, capacity is immediately available that could replace older vessels requiring high operating and maintenance costs and of low reliability due to frequent breakdowns.

147. Ready access to the global charter market allows domestic shipping capacity to adjust more quickly to market demand, and the deployment of chartered foreign vessels can help address the high operating cost of older vessels in the fleet. Provided freedom of entry is maintained, the benefits from such alternative would be passed on to shippers in terms of 
lower shipping rates and improvement in the levels of service. It is therefore important to achieve an appropriate balance between the policy objectives of, on the one hand, ensuring that vessels operating in the coastal trades are registered under the Philippines' flag and are thus taxed appropriately; and on the other hand, fostering the competitiveness of domestic shipping operations.

\section{Restrictions on inputs}

\section{Restrictions on vessel importation for domestic trade}

148. Current efforts to develop the quality and capacity of domestic shipping services are supported by Philippine law. It is the national policy to "encourage the development of a viable shipbuilding and ship repair industry to support the expansion and modernization of the Philippine domestic merchant marine fleet" as stated in RA 9295.

149. Section 20 of RA 9295 imposes restrictions on vessel importation for domestic trade. It requires MARINA to evaluate and determine the progressive capability of Philippine shipyards to build and construct new vessels for the domestic trade. If domestic shipyards are found capable of providing sufficient vessels to meet domestic demand for vessels up to a certain size threshold, then all domestic ship operators will be discouraged from importing new or previously owned vessels that are less than that size for the domestic trade. In the first year, the size threshold was set at 500 GRT, with the intention that this should be increased over time as the capability of domestic shipyards improved.

150. This policy reduces the ability of firms to source their vessels from the most efficient producer. This provision has allowed for the creation of domestic shipyards that can serve the needs of the local shipping companies. Further deregulating this sector would expose these local shipyards to global competition and encourage greater efficiency among these producers.

\section{Requirement for drydocking of domestic vessels in domestic shipyards}

151. Presidential Decree 1221 requires that all Philippine-owned and/or registered vessels undertake all repairs, improvement, alteration, reconditioning, conversion or dry docking with MARINA-registered ship repair yards ${ }^{67}$. MARINA exempts vessels from this requirement only for exceptional cases. These include primarily the Philippine-owned vessels that are engaged in the overseas trade.

152. MARINA Administrator Emerson M. Lorenzo, in his 11 November 2011 address at the Philippine International Maritime Conference at the World Trade Center stated that operators preferred to have their ships dry docked and repaired in foreign shipyards due to lower expenses and shorter downtime. During the interview program, several operators

\footnotetext{
${ }^{67}$ Presidential Decree 1221 Requiring All Philippine - Owned and/or Registered Vessels to Undertake Repairs and Drydocking with Marina-Registered Ship Repair Yards ,17 October 1977
} 
confirmed that this was certainly the case for larger vessels, with the cost of dry docking in the Philippines being up to 50 percent higher than the cost of dry docking overseas. There is only one facility in the Philippines that is able to handle the largest vessels operating in the domestic trade. In the absence of effective competition from overseas facilities, shipowners with large vessels face what is effectively a mandated monopoly for the provision of dry docking services.

\section{MARINA's monitoring capacity of domestic market}

153. MARINA's capability to monitor shipping operations in the whole country is limited and requires significant improvement. It has a limited number of regional offices which is insufficient to monitor all of the country's shipping routes. With the expected reforms of the sector, this, in turn, requires a strong monitoring capability to prevent shipping operators from charging exorbitant rates or failing to provide the required capacities. It must also monitor market shares of shipping operators in specific routes.

154. An established and efficient system to monitor the performance of shipping operators per route would allow MARINA ensuring that, among other responsibilities, monopoly operators do not abuse and set high rates unilaterally or those with more than one operator do not collude in setting high rates. This requires the creation of a systemwide Philippine maritime database to allow marina to constantly monitor the operations of the domestic shipping fleet. 


\section{The way forward}

155. The key task in enhancing the competitiveness of domestic shipping is to ensure the effective operation in the market for shipping services. Many of the recommendations that follow therefore focus on measures that will serve to ensure that some market participants do not enjoy an unfair advantage over others; and measures that lower regulatory barriers to entry.

156. Regulations should focus less on objectives that can be satisfied by market competition, such as entry decisions and pricing, and more towards objectives that require government intervention, such as safety and environmental concerns. The government needs to better deploy its resources to provide oversight over a domestic shipping system that must be both cost-efficient and extremely safe.

157. As such, improving competitiveness also requires reform of regulations that increase the costs faced by all shipping operators. The direction forward therefore includes recommendations to reform regulations on public safety that raise, or may tend to raise, the costs faced by incumbents and new entrants alike. Finally, since markets work more effectively when decisions are based on timely and accurate information, the direction forward includes recommendations designed to improve the quality of information available to both regulators and market participants.

\section{Creating a level playing field}

\section{Remove opportunity for incumbents to object to granting of the CPC}

158. In the present process, an application for a CPC to operate a new service can be challenged by an operator already providing services in the relevant market (MARINA's implementing regulations). The incumbent operators can contest the feasibility study of the new applicant by arguing that the market is too small to accommodate an additional participant and that new entry would not be financially viable.

159. This provision creates the possibility that an incumbent will use the process to delay the entry of a new competitor (as indicated by a small shipping operator); to add to the cost that the competitor faces in entering the market; and, in the extreme case, to block entry altogether. Such a system creates an uneven playing field that benefits incumbents.

\section{Focus CPC conditions on quality standards}

160. Effective competition in domestic shipping requires that all participants are held to the same safety and environmental standards. The process of issuing Certificates of Public Convenience can be a useful regulatory tool in ensuring that this condition is met. The intention that it should do so is clear in RA 9295, which requires that MARINA, in granting an application for a CPC, take into consideration, "the financial capacity of the domestic ship 
operator to provide and sustain safe, reliable, adequate, efficient and economic service" ${ }^{68}$

\section{Facilitating greater competition between operators}

\section{Streamline the CPC process}

161. The application process for a CPC is quite expensive for the applicant due to the application and other MARINA fees, publication requirements and legal fees. Many of these steps are repetitive and may be further streamlined to minimize the processing time and costs for the issuance of the CPC.

162. Once the concept of objection by incumbents is eliminated from the process of awarding a CPC, there is no longer any need for an ex ante quasi-judicial process. This should facilitate a significant reduction in both the time and the cost involved in granting a CPC application, and help refocus MARINA's activities on ensuring that all participants are held to the same safety and environmental standards.

\section{Use a single form of CPC}

163. There seems little to be gained from continuing to formally distinguish between the 2 forms of CPC and the interests of clarity and certainty would be served by eliminating the distinction between "liner" and "tramper" CPCs. Tramp shipping provides an important source of potential new entry on liner routes, and allowing them to freely do so enhances the competitive environment.

\section{Allow greater flexibility within a CPC}

164. Seeking approval imposes additional costs on the shipping operator, as, for each amendment to the CPC, MARINA imposes additional fees. In a market-based system, vessel deployment should be a management prerogative. This could be avoided, while retaining the CPC framework, by allowing an operator, once it has been granted a CPC, to vary the routes and vessels covered by the CPC simply by providing notice to MARINA that it intends to make these changes, rather than seeking approval to make them.

\section{More efficient and cost effective logistics}

\section{Remove requirement to drydock in the Philippines}

165. Current regulations require domestic vessels to undertake their dry docking and ship repair/maintenance requirements in domestic shipyards. This policy actually reduces the level of competition faced by domestic shipyards and increases the costs faced by domestic shipping operators.

\footnotetext{
${ }^{68}$ RA No. 9295, Section 7.
} 
166. Several private shipping companies consulted during the stakeholder engagement process indicated that, particularly for larger ships, they would prefer to have their ships dry docked and repaired in foreign shipyards, indicating that, for the largest vessels, savings of up to $\mathbf{5 0}$ percent of dry docking costs could be saved if this requirement were eliminated.

\section{Remove restrictions on vessel importation for domestic trade}

167. Current regulations impose restrictions on vessel importation for domestic trade. These laws require MARINA to evaluate and determine the capability of registered shipyards to build and construct new vessels for the domestic trade. If MARINA finds there to be domestic capability to meet domestic demand, all domestic ship operators are discouraged from importing new or previously owned vessels that are less than 500 GRT for the domestic trade. This policy reduces the ability of firms to source their vessels from the most efficient producer.

\section{Facilitate the use of chartered foreign vessels}

168. Shipowners' costs can be reduced by ensuring that they have ready access to the pool of vessels available on the global market. Bareboat chartering is an allowable mechanism for firms to lease ships temporarily to test out new routes or new shipping technologies. While the chartering process is still in existence, the current bottleneck involves the difference in interpretation of existing tax policies pertaining to these charters between MARINA and the Department of Finance. This bareboat chartering process should be facilitated to improve the quality and the level of innovation in the domestic shipping market.

\section{Remove nexus between PPA revenue and cargo handling charges}

169. Under current administrative arrangements, PPA regulates the charges that are levied by cargo handling operators. But it is also a commercial beneficiary of increases in those rates: the PPA receives a 10 percent and a 20 percent share of the domestic and foreign cargo handling rates collected, respectively. This creates a conflict of interest for PPA.

170. This is desirable to remove this apparent or real conflict of interest by changing the structure of the fee paid to PPA by cargo handling operators. Rather than setting this fee as a percentage of revenue, it could be specified as a fixed annual charge, or a fixed rate per unit of cargo handled. This would break the nexus between cargo handling charges and PPA revenue, and remove the perception - and the risk - that PPA's regulatory decisions on cargo handling charges are influenced by its commercial interests.

\section{Promoting better decisions}

\section{Improve information on cargo flows and current services}

171. While both MARINA and PPA collect information on the maritime transport system, information on cargo volumes and shipping services is not systematically compiled. Much of the data are captured at the regional level and are not consolidated to provide a system-wide 
snapshot of maritime operations.

172. Better information would be beneficial for a variety of regulatory and planning purposes. With the expected reforms of the sector, MARINA will require a strong monitoring capability in order to detect and remedy market failures as they arise. Better-integrated information should also help support PPA in the execution of its planning functions and in monitoring the performance of particular service provides within its ports.

\section{Freely disseminate information to actual and potential market participants}

173. For the greatest benefit to be derived from investments in maritime data collection, it is important that this data is - to the extent consistent with commercial confidentiality made widely available. By providing greater access to the database, the information can be made more useful to the industry in its entirety. Consequently, competition will be more effective if individual market participants have better access to information and can make strategic decisions in a more timely manner.

\section{Conclusion}

174. The World Bank Group's Trade and Competitiveness Global Practice Group Competition Policy team is committed to helping the government of the Philippines remove barriers to competition in the domestic shipping industry. The study is aimed at creating a more level playing field for domestic shipping firms by highlighting regulations that minimize the ability of firms to properly compete in the market and that contribute to the high operating costs of the industry.

175. The main competition issue identified is that the application process for the license to operate a shipping service in the Philippines can be contested by incumbent operators by arguing that competition will be financially ruinous. This licensing process creates the possibility that an incumbent will use the process to delay the entry of a new competitor; to add to the cost that the competitor faces in entering the market; and, in the extreme case, to block entry altogether

176. Other regulatory barriers have been shown to increase the cost of shipping operations in the country. Philippine regulations require domestic vessels to undertake all drydocking and ship repair requirements in domestic shipyards, even if foreign shipyards are available to conduct the same services for up to 50 percent less cost. Current regulations impose restrictions on vessel importation and assess tax payments for chartered vessels that make short-term chartering uneconomic in many cases. The structure of government fees imposed on private cargo handlers creates a conflict of interest, with the government directly benefiting from fee increases. The industry suffers from a dearth of available data that make government regulation and private sector investment planning very challenging.

177. Reforming these regulations could improve the functioning of the domestic shipping sector. The study estimates that amending the domestic shipping regulations can generate an additional US18 million in annual investment in the domestic shipping sector by 2018. 
ANNEX A: Primary Shipping Routes and Number of Shipping Operators per Route

\begin{tabular}{|c|c|c|c|}
\hline No. & $\begin{array}{l}\text { Route } \\
\text { Origin }\end{array}$ & Destination & No. of Shipping Lines \\
\hline 1 & Bacolod City & Cagayan de Oro & 2 \\
\hline 2 & Bacolod City & Cotabato & 2 \\
\hline 3 & Bacolod City & Dipolog City & 1 \\
\hline 4 & Bacolod City & General Santos City & 1 \\
\hline 5 & Bacolod City & Iligan City & 1 \\
\hline 6 & Bacolod City & Iloilo City & 4 \\
\hline 7 & Bacolod City & Zamboanga City & 2 \\
\hline 8 & Batangas City & Calapan City & 1 \\
\hline 9 & Cagayan de Oro & Dipolog City & 1 \\
\hline 10 & Cagayan de Oro & Iloilo City & 2 \\
\hline 11 & Cagayan de Oro & Nasipit, Agusan del Norte & 1 \\
\hline 12 & Cebu City & Bacolod City & 2 \\
\hline 13 & Cebu City & Cagayan de Oro & 4 \\
\hline 14 & Cebu City & Davao & 2 \\
\hline 15 & Cebu City & Dumaguete City & 2 \\
\hline 16 & Cebu City & Iloilo City & 2 \\
\hline 17 & Cebu City & Nasipit, Agusan del Norte & 2 \\
\hline 18 & Cebu City & Ormoc City & 1 \\
\hline 19 & Cebu City & Ozamis City & 1 \\
\hline 20 & Cebu City & Surigao City & 1 \\
\hline 21 & Cebu City & Zamboanga City & 1 \\
\hline 22 & Cotabato & Zamboanga City & 2 \\
\hline 23 & Cotabato & Dumaguete City & 1 \\
\hline 24 & Cotabato & Iloilo City & 1 \\
\hline 25 & Cotabato & General Santos City & 1 \\
\hline 26 & Davao & Surigao City & 1 \\
\hline 27 & Davao & General Santos City & 3 \\
\hline 28 & Davao & Zamboanga City & 1 \\
\hline 29 & Dumaguete City & Iligan City & 1 \\
\hline 30 & Dumaguete City & Ozamis City & 2 \\
\hline 31 & Dumaguete City & Bacolod City & 1 \\
\hline 32 & Dumaguete City & Zamboanga City & 2 \\
\hline 33 & General Santos City & Zamboanga City & 3 \\
\hline 34 & Iloilo City & Davao & 1 \\
\hline
\end{tabular}


Working paper for comments and subject to change.

\begin{tabular}{|c|c|c|c|}
\hline No. & $\begin{array}{l}\text { Route } \\
\text { Origin }\end{array}$ & Destination & No. of Shipping Lines \\
\hline 35 & Iloilo City & General Santos City & 1 \\
\hline 36 & Iloilo City & Zamboanga City & 3 \\
\hline 37 & Manila & Bacolod City & 4 \\
\hline 38 & Manila & Cagayan de Oro & 5 \\
\hline 39 & Manila & Cotabato & 2 \\
\hline 40 & Manila & Cebu City & 4 \\
\hline 41 & Manila & Davao & 5 \\
\hline 42 & Manila & Dipolog City & 2 \\
\hline 43 & Manila & Dumaguete City & 4 \\
\hline 44 & Manila & General Santos City & 5 \\
\hline 45 & Manila & Iligan City & 2 \\
\hline 46 & Manila & Iloilo City & 4 \\
\hline 47 & Manila & Nasipit, Agusan del Norte & 2 \\
\hline 48 & Manila & Ozamis City & 2 \\
\hline 49 & Manila & Puerto Princesa City & 1 \\
\hline 50 & Manila & Surigao City & 2 \\
\hline 51 & Manila & Tagbilaran City & 1 \\
\hline 52 & Manila & Zamboanga City & 4 \\
\hline 53 & Ozamis & Iligan City & 1 \\
\hline 54 & Surigao City & Nasipit, Agusan del Norte & 1 \\
\hline
\end{tabular}

Source: MARINA List of Certificates of Public Convenience 
ANNEX B: Review of Relevant Reports

\begin{tabular}{|c|c|c|c|}
\hline Report & Main findings & Main recommendations & Economic sector \\
\hline $\begin{array}{l}\text { Liner Shipping Route Study, Final } \\
\text { Report - Volume II Shipping Cost } \\
\text { and Rate Analysis. Nathan } \\
\text { Associates Inc. 1994. Manila: } \\
\text { United States Agency for } \\
\text { International Development. }\end{array}$ & $\begin{array}{l}\text { Need for a tariff structure in } \\
\text { shipping that would accurately } \\
\text { reflect the costs of the liner } \\
\text { operations. }\end{array}$ & $\begin{array}{l}\text { 1. A fork tariff for } 1991 \text { that would } \\
\text { provide a range of flexible freight rates } \\
\text { within the industry to meet variable } \\
\text { trading conditions and various } \\
\text { productivity levels. } 2 \text {. A rate-monitoring } \\
\text { system that would facilitate monitoring } \\
\text { by MARINA and the Philippine Shippers' } \\
\text { Council (SHIPPERCON) of actual user } \\
\text { charges versus authorized rates. } 3 . \\
\text { Develop the mechanics for periodic } \\
\text { adjustment of the fork tariff after } 1991 .\end{array}$ & Maritime Transportation \\
\hline $\begin{array}{l}\text { Philippine Domestic Shipping } \\
\text { Industry: State of Competition } \\
\text { and Market Structure-Myrna S. } \\
\text { Austria PASCN Discussion Paper } \\
\text { No. 2002-04, Philippine Institute } \\
\text { for Development Studies }\end{array}$ & $\begin{array}{l}\text { 1. The shipping industry is a highly } \\
\text { contestable market in the absence } \\
\text { of government regulations that } \\
\text { prevent market forces take their } \\
\text { course on the functioning of the } \\
\text { industry. } 2 \text {. Rate discounting, } \\
\text { particularly on freight rates, is a } \\
\text { common practice in the industry } 3 . \\
\text { The past regulations of the } \\
\text { domestic shipping industry had } \\
\text { adverse impacts on the economy. } \\
4 \text {. The Herfindahl-Hirschman Index } \\
\text { (HHI) shows that the domestic } \\
\text { shipping industry is highly }\end{array}$ & $\begin{array}{l}\text { Liberalization and deregulation should } \\
\text { not be undertaken in isolation. The } \\
\text { policy reforms should be complemented } \\
\text { by competition policy to ensure that the } \\
\text { competition and other benefits arising } \\
\text { from liberalization and deregulation are } \\
\text { not eroded by possible development of } \\
\text { market power among shipping lines. } \\
\text { Two other significant areas for reform } \\
\text { are the ceiling on the return on } \\
\text { investment and the application of the } \\
\text { revenue deficiency method for upward } \\
\text { adjustment of regulated rates. Both are } \\
\text { anti-competitive. }\end{array}$ & Maritime Transportation \\
\hline
\end{tabular}




\begin{tabular}{|c|c|c|c|}
\hline Report & Main findings & Main recommendations & Economic sector \\
\hline & $\begin{array}{l}\text { concentrated } 5 . \text { Analysis of the } \\
\text { different routes shows that the top } \\
\text { five players operate most of the } \\
\text { primary routes; } 6 . \text { About } 50 \text { percent } \\
\text { of the primary routes have at least } \\
2 \text { operators and the remaining } 50 \\
\text { percent only have one operator } 7 . A \\
\text { further analysis of the individual } \\
\text { routes shows that operators have } \\
\text { their own niche markets }\end{array}$ & & \\
\hline $\begin{array}{l}\text { Competition Policy and } \\
\text { Regulation in Ports and Shipping, } \\
\text { Gilberto M. Llanto, Enrico L. } \\
\text { Basilio, and Leilanie Q. Basilio, } \\
\text { Research Paper Series No. 2007- } \\
\text { 04, Philippine Institute for } \\
\text { Development Studies }\end{array}$ & $\begin{array}{l}\text { 1. Several issues arise from the } \\
\text { policy, regulatory, and institutional } \\
\text { framework of the ports sector that } \\
\text { have constrained competition and } \\
\text { provided burdensome regulation. } \\
\text { 2. PPA has multiple roles as a } \\
\text { developer, operator, maintainer, } \\
\text { and regulator. This highly } \\
\text { centralized port ownership and } \\
\text { administration system leads to } \\
\text { conflict of functions and interest } \\
\text { problems. 3. The export of } \\
\text { manufactured goods by ocean } \\
\text { transport is at a disadvantage } \\
\text { because Main Line Container } \\
\text { Operators do not make direct calls } \\
\text { to Manila, but rather use common } \\
\text { carrier feeders to transport cargo }\end{array}$ & $\begin{array}{l}\text { Amend the charter of the PPA to remove } \\
\text { conflict-of-interest provisions and to } \\
\text { separate the regulatory function from } \\
\text { the development function; Require the } \\
\text { PPA to have transparent and } \\
\text { competitive bidding procedures on } \\
\text { granting or extending cargo handling } \\
\text { contracts; Revoke the PPA's } \\
\text { Administrative Order 01-2001; Require } \\
\text { transparent accounting and reporting } \\
\text { standards for the enforcement of port } \\
\text { charges and shipping rates; Replace the } \\
\text { present practice of the PPA sharing in } \\
\text { port fees and other charges with a } \\
\text { (regulatory) fee for services rendered; } \\
\text { Promote the development of RRTS as a } \\
\text { parallel system to PPA ports and remove } \\
\text { the cargo handling fees on RORO cargo }\end{array}$ & $\begin{array}{l}\text { Maritime Transportation } \\
\text { Ports }\end{array}$ \\
\hline
\end{tabular}




\begin{tabular}{|c|c|c|c|}
\hline Report & Main findings & Main recommendations & Economic sector \\
\hline & $\begin{array}{l}\text { to and from their regional hubs } \\
\text { such as Hong Kong and Singapore. } \\
\text { 4. Exports also face the problem of } \\
\text { inefficient inter-island container } \\
\text { handling facilities and shipping } \\
\text { services. } 5 \text {. The domestic shipping } \\
\text { industry has remained very } \\
\text { concentrated, with five shipping } \\
\text { companies accounting for } 90 \\
\text { percent of passenger and cargo } \\
\text { markets and almost all of the } \\
\text { primary and secondary shipping } \\
\text { routes. }\end{array}$ & $\begin{array}{l}\text { when no corresponding service is } \\
\text { offered; and Continue the privatization } \\
\text { of operations in PPA ports and terminals } \\
\text { and the designation of private } \\
\text { noncommercial ports into private } \\
\text { commercial ports. Require MARINA to } \\
\text { review its policies and regulations to } \\
\text { uphold competition and the protection } \\
\text { of consumers from the exercise of } \\
\text { market power; Require MARINA to have } \\
\text { clear and transparent procedures for } \\
\text { route licensing; and Strictly enforce } \\
\text { maritime safety regulations and } \\
\text { inspection of vessels to check } \\
\text { seaworthiness and provide effective } \\
\text { training programs on maritime safety. }\end{array}$ & \\
\hline $\begin{array}{l}\text { The Philippine Port Sector PPA: A } \\
\text { Case of Regulatory Capture, } \\
\text { Enrico L. Basilio, Paper presented } \\
\text { during the International } \\
\text { Conference on Challenges to } \\
\text { Development: Innovation and } \\
\text { Change in Regulation and } \\
\text { Competition at the Edsa Plaza } \\
\text { Hotel on October 13-15, } 2003\end{array}$ & $\begin{array}{l}\text { 1. The administration of the } \\
\text { Philippine port system is highly } \\
\text { centralized. } 2 \text {. Policy formulation } \\
\text { and implementation lacks } \\
\text { transparency and, in most cases - } \\
\text { railroaded. This happens because } \\
\text { private sector participation in policy } \\
\text { formulation and implementation is } \\
\text { virtually non-existent. }\end{array}$ & $\begin{array}{l}\text { Amend the PPA Charter to make it more } \\
\text { dynamic and responsive to the needs of } \\
\text { the port users and the economy in } \\
\text { general requires legislative action. }\end{array}$ & Ports \\
\hline
\end{tabular}

